\title{
Okul Müdürü Olmanın Anlamı Üzerine Bir Olgubilim Çalışması
}

\author{
DOI: $10.26466 /$ opus. 885162
}

$*$

\author{
Pinar Yengin Sarpkaya * \\ * Doç. Dr., Aydın Adnan Menderes Üniversitesi, Eğitim Fakültesi, Aydın/Türkiye \\ E-Posta: pinar@sarpkaya.net \\ ORCID: $\underline{0000-0001-8379-7083}$
}

\section{Öz}

Bu çalışma, okul müdürlüğünün anlamın bu mesleği deneyimleyen okul müdürlerinin görrüslerine dayanarak betimlemeyi amaçlayan bir olgubilim araştırmasıdır. Veriler, maksimum çeşitlilik örneklemesiyle belirlenen 14 okul müdürüyle, araştırmacı tarafından geliştirilmiş görüşme formu aracılı̆̆ıyla yapılan görüşmelerle elde edilmiştir. İçerik çözümlemesi yapılarak elde edilen bulgular, yedi tema altında toplanmıştır. Katılımcıların müdürlüğ̈̈ seçme nedenleri içsel güdülenmeye ya da eğitime yararl olmaya dayanmaktadır. Müdürlü̈̆̈̈n en zor/uğraştırıcı yönü "okul işletmesinin yönetimi" kapsamındaki konulardır. Resmi okul müdürleri, okulun eğitime hazır olması için gereken finansman bulmak, temizlik personeli sağlamak gibi asgari ihtiyaçları karşllama zorlukların vurgularken özel okul müdürü, sistem laboratuvarı gibi eğitimin niteliğini artırmaya dönük ihtiyaçları vurgulamıştır. Öğretimsel liderliğe zaman bulmak bazı müdürler için ciddi bir zorluktur. En keyif verici yönle ilgili bulgular genel olarak, yapılan çalışmaların başarıya ulaştığın görme; öğrenci veli ve öğretmenlerin mutlu olduğunu görme ve olumlu geribildirim almaya dayanmaktadır. Katılımcilar, müdür olmaya anlam yüklemelerini deneyimlerinden hareketle yapmakta; önder, temsilci olma gibi anlamlar yanında her şeyden sorumlu olma, okulun ihtiyaçların karşılama gibi rutin roller de yüklemektedirler. Yüklenen bir anlam da zaman sınırı olmadan çalışmak şeklindedir. Müdürler okul müdürü olmaktan dolayı çoğunlukla olumlu duygular yaşamaktadırlar. Katılımcıların, zorluklarına karşın müdür olmaktan hoşnut olduklar belirlenmiştir. Elde edilen bulgular doğrultusunda öneriler geliştirilmiştir.

Anahtar Kelimeler: Okul müdürü, müdürlük, fenomenoloji, rol. 


\title{
A Phenomenological Study on The Meaning of Being School Principal
}

\begin{abstract}
This study is a phenomenological research aiming to describe the meaning of school headship based on the opinions of school principals who have experienced this profession. The data were obtained via interviews with 14 school principals who were determined by the maximum diversity sampling, through the interview form developed by the researcher. Findings obtained through content analysis were grouped under seven themes. Participants' reasons for choosing the headship are based on intrinsic motivation or being useful to education. The most difficult / challenging aspect of the headship is the subjects within the scope of "management of the school organization". Public school principals emphasized the difficulties of meeting the basic needs such as finding the necessary budget, providing cleaning staff for the school to be ready for education, while private school principal emphasized the needs to increase the quality of education such as system laboratory. Finding time for instructional leadership is a serious challenge for some principals. Findings about the most enjoyable aspects are, in general, to see that the studies have been successful, to see that students, parents and teachers are happy, and to receive positive feedback. Participants attribute meaning to being a principal based on their experiences; in addition to meanings such as being leader and representative, they also attribute to routine roles such as being responsible for everything and meeting the needs of the school. One of the attributed meanings is to work without time limits. Principals mostly experience positive feelings for being the principal. It was determined that the participants were satisfied with being an administrator despite their difficulties. Suggestions were developed in line with the findings.
\end{abstract}

Keywords: School principal, headship, phenomenology, role. 


\section{Giriş}

Okullar bir ülkenin eğitim sistemini amaçlarına ulaştırmak üzere kurulan temel birimlerdir. Bu birimlerin niteliği her şeyden önce öğretmenin niteliğine bağlıdır. Uzun dönemde bakıldığında öğretmenin güdülenmesi, yönlendirilmesi ve mesleki gelişiminin sağlanmasında okul müdürünün rolünün kritik olduğu görülür. Ayrıca eğitim programlarının etkili yönetilmesi, çalışmalar arasında eşgüdümün sağlanması, güçlü bir okul ikliminin ve kültürünün oluşturulması, nitelikli bir eğitim için okulun iç paydaşlarına liderlik yapılması, etkili kararların alınması güçlü bir okul yöneticisi ile mümkün olabilmektedir. Bu anlamda okul müdürü, her toplumda ve her dönemde önemli olmuştur. Ancak bilgi ve iletişim teknolojilerinin gelişmesiyle okulun bilgi aktarıcılık rolünün azalarak öğrenmeyi kılavuzlama rolünün ön plana çıkması, neoliberal politikaların işletmeci yönetim anlayışını dayatması, hızlı değişimin okulları çok yönlü ve sürekli bir baskı altına sokması, kapsayıcı eğitime ihtiyacın artması, pek çok ülkede gelir ve olanak eşitsizliklerinin artmasl; okul müdürünün rollerini karmaşıklaştırmıştır.

Son yıllarda okul müdüründen beklentilere, okul müdürlüğünün nasıl gerçekleştirilmesi gerektiğine ya da okul müdürünün bazı nitelikleri ne kadar taşıdığına ilişkin araştırmalar artmıştır. Ancak, paydaşların, okul müdürünü ve müdürlüğünü nasıl gördüğü kadar, okul müdürlerinin kendi konumlarını ve deneyimlerini nasıl anlamlandırdıkları da önemlidir. Ayrıca, TALIS'in (Teaching and Learning International Survey) (OECD, 2020) ortaya koyduğuna göre Türkiye'de öğretmenlerin yaş ortalaması 36 'dır (OECD ortalaması 44) ve öğretmenlerin yalnızca \%6'sı 50 yaş üzerindedir. $\mathrm{Bu}$, önümüzdeki on yılda Türkiye'de öğretmenlerin onda birinden daha azının değişeceği anlamına gelmektedir. Bu genç öğretim kadrosunu yönlendiren ve onların çalıştığı okulu yöneten müdürlerin kendi mesleklerini (müdürlüğü) nasıl gördüklerini anlamak, hem okul müdürlüğüne ilişkin olası sorun alanların görmek hem de geleceğe ilişkin bir vizyon belirlemek açısından gereklidir. Çünkü böyle bir araştırma, içeriden bir bakış anlamına gelmekte, müdür olmayanların bakışıyla fark edilemeyecek ayrıntıları ortaya koyma potansiyeli taşımaktadır. Bu nedenle bu çalışmada okul müdürlerinin perspektifinden okul müdürlüğünü anlamaya odaklanılmıştır. 


\section{Kuramsal Arkaplan}

Yönetim, işleri başkalarıyla ve başkaları aracılığıyla etkili ve verimli bir şekilde yerine getirme (Robbins, Decenzo ve Coulter, 2017; Sergiovanni, Kelleher, Mc. Carthy ve Wirt, 2004), örgütün amaçlarına ulaşması için kaynakları etkili şekilde kullandırma ve insanları yönlendirme sürecidir (Amadi, 2008). Örgüt bir yapı, yönetim de bu yapıyı işleten bir süreçtir. Bu bağlamda okul yönetiminin görevi de okulu amaçlarına uygun olarak yaşatmaktır (Bursalığlu, 2015; Bush, 2003). Okul müdürü eğitim sistemi içinde bir ara yönetici, okulunda ise tepe yöneticisidir. Bu nedenle okulun, devletin kuruluş felsefesine uygun olarak eğitim sistemi için belirlenen amaçlara ulaşmaya hizmet edecek şekilde çalıştırılması ve geliştirilmesi sorumluluğu, öncelikle okul müdürünündür.

Okul liderliğinin öğrenci öğrenmesi üzerinde sinıf öğretiminden sonra ikinci sırada olduğu ve hem başarılı hem başarısız okulların, başarı durumlarını liderliğin yüksek ya da düşük etkisine bağladığı belirlenmiştir (Leithwood, Harris, ve Hopkins, 2008). Tüm dünyada nitelikli eğitime ilginin artması, özellikle gelişmekte olan ülkelerde ailelerin okuldan beklentisinin artması biçiminde de karşımıza çıkmaktadır. OECD'nin Bir Bakışta Eğitim Türkiye ülke notlarına (OECD, 2017) göre 2015'te lise altı eğitimliler lise derecesine sahip olanlardan \%30 (OECD ortalamas1 \%22) daha az, yükseköğretim derecesine sahip olanlar lise mezunlarından \%67 (OECD ortalaması \%56) daha fazla kazanmıştır. Bu da günümüz koşullarında eğitimden beklentinin, böylece okul çalışanları ve özellikle müdürler üzerinde başarı baskısının artmasını getirmektedir.

Etkili okullar ve yöneticilerin öğrenci öğrenmesinde fark yarattığı kabul edilir (Balc1, 2002; Coelli ve Green, 2012; Hanson, 2003; Sergiovanni vd., 2004). Başarılı okullarda öğretmenler öğrenci eğitimi konusunda kendilerini, birbirlerini tamamlayıcı ve ortak bir çalışma girişiminin bir parçası olarak görürler (Glickman, Gordon ve Ross-Gordon, 2009). Öğretmenlerin bu tamamlayıcı ve takım halinde çalışma becerilerinin geliştirilmesinde okul yöneticileri önemli rol oynar (Holland, 2009; Hord, 1998). Bu nedenle örgütteki diğer çalışanlara nezaret eden ve onları yönlendiren kişiler olarak yöneticilerin (Robbins vd., 2017) çok çeşitli rolleri yerine getirmesi ve bunu başarmak için çeşitli becerilere sahip olması gerekir. 
Mintzberg (2017), yöneticilerin rollerini, formal otoriteden gelen bireyler arası, bilgiye dayalı ve karar rolleri olarak siralar. Bireylerarası roller, kurumu temsil etme, liderlik ve irtibat rolleridir. Yönetici, astlarıyla ve iletişim ağındaki kişilerle etkileşimi sayesinde bilgilendirme rollerini yerine getirir ve örgütün sinir merkezi durumuna gelir. Bireyler arası roller ve bilgilendirme rolleri yöneticinin karar verici olarak başarılı olmasını sağlar. Bu sınıflandırma çeşitlenerek ve okula uyarlanarak pek çok araştırmacı tarafından değişik şekillerde ele alınmıştır. Sharp ve Walter (2003), okul yöneticilerinin ögretimsel liderlik ve okul yönetme olmak üzere iki grup rolü olduğunu aktarır. Yapılan araştırmalardan hareketle, müdürlerin en çok personel, finansal yönetim, zaman planlaması gibi yönetsel konulara zaman harcadıklarını ama aslında eğitim liderliği, gözetim, genel planlama, program geliştirme gibi öğretimsel konulara zaman ayırmak istediklerini belirtir. Mintzberg (2017) genel literatürde bulunan, Taylor'dan ve Fayol'dan beri yöneticilerin yansıtıcı, sistematik planlayıcılar olduğu görüşünün doğru olmadığını belirtir. Yöneticinin planlama yapıp sonra da orkestra şefi gibi yönettiğini ve olağanüstü durumlar dışında kenardan izlediğini düşünmenin araştırmalarla doğrulanmadığını belirtir. Okul müdürleri için de benzer bulgular vurgulanmaktadır. Müdürlerin zamanlarının yarısını ofislerinde geçirirken yarısını ofis dışında geçirdikleri (Fullan, 2008; Horng, Klasik, ve Loeb, 2010) bu anlamda bireyler arası rollerinin ön plana çıktığı belirtilmektedir. Araştırmalar, müdürlerin rollerindeki değişimi de ele almakta; finansal konular ve işletmecilik rolü, öğretmenin mesleki gelişimini sağlama ile otorite anlayışı, sorumluluk, öğretim programı ve uygulamalarının geliştirilmesi, personeli değerlendirme, okula dair politikaların oluşturulması, karara katılım gibi konuları (Balyer, 2012; Fullan, 2018; Gümüşeli, 2001; Hord, 1988; Kılıç, 2020) ön plana çıkarmaktadır.

Yöneticilerin rollerini yerine getirebilmek için kavramsal, teknik ve beşeri becerilere sahip olması gerektiği ortaya konmuştur (Katz, 2009). Kavramsal beceriyi, yöneticilerin sorun çözme becerisi ve yeterliği olarak ele alan yazarlar (Güçlü, 1996; Robbins vd., 2017) vardır. Sorun çözme örgütün çeşitli işlevlerinin birbirine nasıl bağımlı olduğunu ve herhangi bir bölümdeki değişikliklerin diğerlerini nasıl etkilediğini tanımayı içerir. Bu, ilişkileri tanımaya ve her durumda önemli unsurları algılamaya dayanır. Bunu yapabilen yönetici, tüm örgütün refahını geliştiren şekilde hareket edebilir (Katz, 2009). İnsanc1 bir örgüt kurma, insancll bir denetim sistemi kurma ve eğitim 
programı oluşturma arasındaki bağı anlayabilme; kavramsal beceriye örnek olarak verilebilir (Sergiovanni ve Starratt, 1979). İnsani yeterlik, gelişmiş bir iletişim yeterliğine sahip olmayı, kendi tutumlarının, varsayımlarının, başka insanlar ve gruplar hakkındaki inançlarının farkında olmayı (Katz, 2009), başkalarını anlama kadar kendini anlamayı (Sergiovanni ve Starratt, 1979) ifade eder. Teknik beceri, yöntem, süreç, resmi iş ve işlemlerin başarılabilmesi (Can, 1992), uzmanlık bilgisi ve deneyimine dayanan işe özgü bilgi ve tekniklerin (Robbins vd., 2017; Başaran, 1992) bilinmesi anlamına gelir. Bir eğitim yöneticisi için öğretim yöntem ve teknikleri, süreçleri ve işlemleri konusunda uzman olmak, bu yeterliğe örnek verilebilir (Açıgöz, 1994). Ayrıca güç tabanı oluşturmak ve etkili bağlantılar kurmak için yöneticilerin politik becerilere de sahip olması gerektiği belirtilir (Robbins vd., .2017). Ek olarak özellikle günümüzde öğrenme ve yenilikçilik, bilgi, medya ve teknoloji ile yaşam ve kariyer becerileri, okul müdürünün sahip olması gereken 21. yüzyıl becerileridir. (Battelle for Kids, 2019). Okul müdürlerinin kendilerinden beklenen rolleri yerine getirebilmeleri için, eğitim sistemi ve okul yönetiminin değişen rollerinden ve bu rolleri etkileyen çevresel dinamiklerden haberdar olmaları (Gümüşeli, 2001) ve çok yönlü beceriler geliştirmiş olmaları gerekir.

Pek çok ülkede okul müdürlüğü yapabilmek için öğretmen olmak bir önkoşuldur ve Türkiye'de de böyle olması yerinde bir uygulamadır (Şişman ve Turan, 2004). Ancak bu durum, müdürlügü̈n meslekleşmesi için yeterli değildir. Türkiye, okul yöneticilerinin seçimi, atanması ve sürekli mesleki eğitimleri konusunda bir okul yöneticiliği modeli geliştirememiştir (Ağaoğlu, Altınkurt, Yılmaz ve Karaköse, 2012; Kesen, Toklucu, Sundaram, Abaslı; 2019). Bu gerçek, okul yöneticisi seçme yönetmeliğinde çok sık yapılan değişikliklerde de somutlaşmakta, bir dönem geçerli olan ölçütler ve ilkeler bir sonraki dönemde geçersiz olabilmektedir. Pek çok üniversitede eğitim yöneticisi yetiştirmeye yönelik yüksek lisans ve doktora programları bulunsa da yönetici atama ölçütleri ile bu programlar arasında hâlâ işlevsel bir bağ kurulamamıştır. Bu haliyle yöneticilik, öğretmenliğin bir yan dalı gibi görülmekte ve bütün bunlar, okul müdürlüğünün meslek olarak algılanmasını zorlaştırmaktadır. OECD ülkelerinde genel olarak okul müdürleri öğretmenlerden daha yüksek bir eğitim almıştır ve müdürlüğe yönelik bir eğitim almış olan müdürlerin oranı OECD ülkelerinde ortalama \%54, Türkiye'de \%30'dur (OECD, 2020). 
Okul yöneticiliğinin öznesi olan okul müdürlerinin görevlerini nasıl anlamlandırdıklarını anlamak, süreci geliştirme ve geleceği şekillendirme açısından önemlidir. Ancak eğitim yönetimi alanyazınındaki araştırmalar, çoğunlukla okul yöneticisinin dışındaki paydaşların katılımıyla yapılmıştır. Okul müdürü olmanın anlamı üzerine yapılan araştırmalar oldukça sınırlıdır. Müdürlügün ne olduğu, özellikleri, nasıl olması gerektiği gibi konularda doğrudan okul müdürleriyle yapılmış sınırlı sayıda çalışmaya ulaşılabilmiştir. Çelikten'in (2004a) kadın okul müdürleriyle yaptığı çalışma, Çelikten'in (2004b) bir kadın okul müdürünü bir dönem boyunca görevi başında gözlemleyerek yaptığı çalışma, Gürbüz, Erdem ve Yıldırım'ın (2013) başarılı okul müdürleriyle görüşmelerine dayanan çalışmaları, okul müdürlüğünü anlamaya hizmet etmektedir. Ancak tam olarak okul müdürü olmanın anlamı üzerine yapılmış çalışmalar değildir. Türkçe alanyazında doğrudan okul müdürlüğünün anlamı üzerine yapılmış iki çalışmaya ulaşılabilmiştir. Bunlardan biri olan Acar'ın (2019) çalışmasına göre okul yöneticileri göreve başladıktan sonra yaşayarak öğrenmekte ve hizmet içi eğitimler yeterli olmamakta; görev ve sorumlulukların çok fazla olması, sorunlar yaratmaktadır. Okul müdürlügünün anlamı üzerine yapılmış olan diğer çalışma Demirtaş ve Özer'e (2014) aittir. Bu araştırmaya göre müdürler, müdürün okulun lideri olması, seçilen kişinin hizmet öncesi bir eğitim aldıktan sonra deneyimli bir yönetici yanında usta-çırak ilişkisi ile yetiştirilmesi gerektiğini düşünmektedirler. Uluslararası ulaşılabilir alanyazında da doğrudan okul müdürlerinin müdürlüğe ilişkin algılarını inceleyen bir araştırmaya rastlanmamıştır; fakat iki araştırma (Morgan, 2018; Trnavčevič ve Roncelli Vaupot, 2009) müdür yardımclarının ve aday müdürlerin müdürlüğe bakışlarını incelemiştir.

Müdür olmanın anlamını; müdürlüğü deneyimleyen bireylerin penceresinden görmek önemlidir. Müdürlerin görüşlerine başvuran mevcut çalışmayla, hem bu kritik görevi yerine getiren bireylerin bakış açısını anlamak hem de okul müdürünün müdürlük rolüne yüklediği anlamı görmek amaçlanmıştır. Bunun sağlanması okul müdürlüğü konusundaki karar alıcılar başta olmak üzere, okulun iç ve diş paydaşlarının müdürün gözünden müdürü ve müdürlüğü anlamalarına yardım edebilir. Geçmişin bilgileri değerlidir, ancak geleceğe yön verebilmek için bugünü doğru yorumlamak gerekmektedir. Bu çalışmanın, bugünü anlamaya hizmet edeceği umulmaktadır. Bu nedenle araştırmanın problem cümlesi “Okul müdürlerine göre okul 
müdürü olmanın anlamı nedir?" biçiminde ifade edilmiştir. Bu probleme bağlı olarak aşağıdaki sorulara yanıt aranmıştır:

1. Okul müdürleri, neden müdür olmayı seçmişlerdir?

2. Okul müdürlerine göre müdür olmanın en zor ya da uğraştırıcı yönü nedir?

3. Okul müdürlerine göre müdür olmanın en keyif verici yönü nedir?

4. Okul müdürlerine göre müdürün sahip olması gereken kritik özellikler nelerdir?

5. Okul müdürleri, müdür olmaya nasıl bir anlam yüklemektedirler?

6. Okul müdürü olmak, müdürlere nasil bir duygu yaşatmaktadır?

7. Okul müdürleri, okul müdürünü hangi metaforlarla açıklamaktadır?

\section{Yöntem}

\section{Araştırma deseni}

Araştırma, nitel araştırma desenlerinden olgubilime göre tasarlanmıştır. Okul müdürlüğünü bireysel gözlem ve deneyimlerimizle tanıyor olsak da bu görevi yerine getirenlerin deneyimlerinden ve görüşlerinden hareketle tanımak önemlidir. Olgubilim deseni, bildiğimiz ama ayrıntılı görüş sahibi olmadığımız olguları, onları deneyimleyen bireylerin katkısıyla ortaya koymayı amaçladığından (Creswell, 2016; Patton, 2014) bu araştırma için en uygun desen olarak görülmüştür.

\section{Çalışma grubu}

Araştırmanın çalışma grubu, Türkiye'de (Aydın ilinde) okul yöneticisi olarak görev yapan 14 okul müdüründen oluşmaktadır. Çalışma grubunun belirlenmesinde en az altı aydır okul müdürlüğü yapıyor olmak ölçütü dikkate alınmıştır. Ayrıca maksimum çeşitlilik örneklemesi yapılarak cinsiyet, kıdem, öğrenim durumu ve görev yapılan okul kademesi açısından çeşitlilik sağlanmıştır. 
Tablo 1. Çalışma grubuna ait bilgiler

\begin{tabular}{llllll}
\hline Kod adi & Cinsiyet & $\begin{array}{l}\text { Okul } \\
\text { Kademesi }\end{array}$ & $\begin{array}{l}\text { Toplam } \\
\text { Kıdem }\end{array}$ & $\begin{array}{l}\text { Müdürlük } \\
\text { Kıdemi }\end{array}$ & $\begin{array}{l}\text { Eğitim } \\
\text { Durumu }\end{array}$ \\
\hline Berna & K & Anaokulu & 12 & 10 & Y. Lisans \\
Ekrem & E & Anaokulu & 11 & 4 & Lisans \\
Sare & K & İkokul & 18 & 3 & Y. Lisans \\
Osman & E & İlkokul & 23 & 13 & Lisans \\
Yavuz & E & İlkokul & 17 & 10 & Lisans \\
Illker & E & İlkokul & 25 & 11 & Lisans \\
Ayhan & E & Ortaokul & 26 & 6 & Y. Lisans \\
Fulya & K & Ortaokul & 38 & 6 & Lisans \\
Cem & E & Ortaokul & 27 & 6 & Lisans \\
Ekin & E & Meslek lisesi & 26 & 23 & Y. Lisans \\
Canan & K & Meslek lisesi & 29 & 7 & Lisans \\
Fuat & E & Genel lise & 15 & 1 & Y. Lisans \\
Firat & E & Genel lise & 23 & 4 & Y. Lisans \\
Selim & E & Ortaokul+lise(özel) & 24 & 6 & Y. Lisans \\
\hline
\end{tabular}

Tablo 1'de görüldüğü gibi, araştırmanın çalışma grubunu oluşturan okul müdürlerinin dördü kadın, onu erkektir; ikisi anaokulu, dördü ilkokul, üçü ortaokul, ikisi meslek lisesi, ikisi genel lise ve biri ortak ortaokul ve lise müdürüdür; on biri resmi, biri özel okul yönetmektedir. Müdürlerin eğitim kurumlarındaki toplam kıdemleri 11 ile 38 yıl arasında; müdürlük kıdemleri ise bir ile 23 yıl arasında değişmektedir. Çalışma grubundaki müdürlerin yedisi yüksek lisans, yedisi lisans mezunudur.

\section{Verilerin toplanması ve çözümlenmesi}

Araştırmanın verileri araştırmacının müdürlerle yaptığı görüşmeler aracıl1ğıyla elde edilmiştir. Görüşmeler için araştırmacı tarafından hazırlanan ve üç uzmanın görüşüyle son şekli verilen "Okul Müdürü Olmanın Anlamı Üzerine Yönetici Görüşleri Formu"ndan yararlanılmıştır. Bu formda kişisel özelliklerle ilgili altı ve araştırma konusuyla ilgili dokuz soru yer almıştır. Bu sorular, "Müdür olmanın keyif veren yönleri için neler söyleyebilirsiniz?" “Okul müdürü olduğunuzu düşündüğünüzde neler hissediyorsunuz? Yani bu görev, bu meslek sizde hangi duyguları yaratıyor?" gibi araştırma problemine dönük olarak müdürlerin rahat açıklama yapabileceği şekilde ifade edilmiştir. Görüşme sırasında ikincil, üçüncül sorularla konuşma ayrıntılandırılmıştır.

Veriler, okul müdürlerinden telefonla randevu alınarak, internet bağlantısı kullanarak görüntü ve ses kaydı alınarak yapılmıştır. Görüşmeler 35 ile 
61 dakika arasında sürmüştür. Görüşme ses kayıtları, sesi yazıya geçiren bir uygulamadan yararlanılarak bilgisayar ortaminda MS Word belgesi haline getirilmiştir. Elde edilen belgedeki yazım hataları, ses kayıtları yeniden dinlenerek düzeltilmiştir.

Görüşme verilerinde her katılımcıya kod adı verilerek içerik çözümlemesi yapılmıştır. Önce tüm görüşme metinleri iki kez okunmuş, daha sonra her katılımcının görüşmesindeki anlamlı birimlere kod adları verilmiştir. Çözümleme sırasında görüşülenin bir görüşme sorusuna verdiği yanıtın içinde başka bir alt problemle ilişkili ifadeler varsa bunlar yine de kodlanmıştr. Tüm katılımcıların verileri kodlandıktan sonra, kodlar arasında ifade/terim birliği sağlanmış, sonra da kodlanan bu her kategori ilişkili olabileceği üst bir kategorinin altına yerleştirilmiştir. Bu aşamada, araştırmanın bir olgubilim çalışması olduğu göz önünde bulundurularak bütünsel bakış açısının gözden kaçmasına neden olabilecek (Ersoy, 2007) ayrıntıların birleştirilmesi yoluna gidilmiştir. Oluşturulan üst kategoriler, araştırmanın alt problemleri birer tema olarak kabul edilip bu temalar altına yerleştirilmiştir. Çözümleme sonunda yedi tema ve 27 kategori ortaya çıkmıştır.

Araştırmanın tutarlılığına yönelik olarak, görüşmeler sırasında, katılımcının anlattıkları ara ara özetlenerek "Böyle mi söylediniz?" gibi sorularla yanlış anlamaların önüne geçilmiş, gerçekten katılımcının üzerinde durduğu noktanın anlaşıldığından emin olunmaya çalışılmıştır. Ayrıca çözümleme sırasında ve sonunda ortaya çıkan kodların alanyazında karşılığının bulunmasına özen gösterilmiştir. Hem çözümleme sırasında hem de sonunda bir eğitim yönetimi öğretim üyesiyle görüş alışverişi yapılmıştır. Ayrıca kodlayıcı tutarlılığını sağlamak için iki öğretim elemanına kodlar sunularak uyum sağlanmayan kodlar üzerinde birlikte çalışılmıştır. İnand1rıcılı̆̆1 sağlamak için de hem araştırma süreci ayrıntılı olarak raporda yer almış hem de katılımcıların görüşlerinden doğrudan alıntılarla bulgular desteklenmiştir. Araştırmanın etik açıdan uygunluğunu sağlamak için gerekli izinler ve etik kurul raporu alınmış ve çalışmada katılımcıların kimliğini ve okullarını belirlemeye olanak verecek bütün bilgiler kodlanmıştır.

\section{Bulgular}

Araştırma verilerinin analiziyle ulaşılan bulgular, araştırmanın alt problemleriyle uyumlu olarak yedi tema ve bu temaların altında 27 kategori şeklin- 
de sunulmuştur. Bu yedi tema önce Şekil 1'de toplu olarak sunulmuş daha sonra her tema ve içerdiği kategoriler ile onların alt kategorileri verilerek ayrıntılandırılmıştır. Ayrıca katılımcıların ifadelerinden bazı doğrudan alıntllar sunularak bulgular genişletilmiştir.

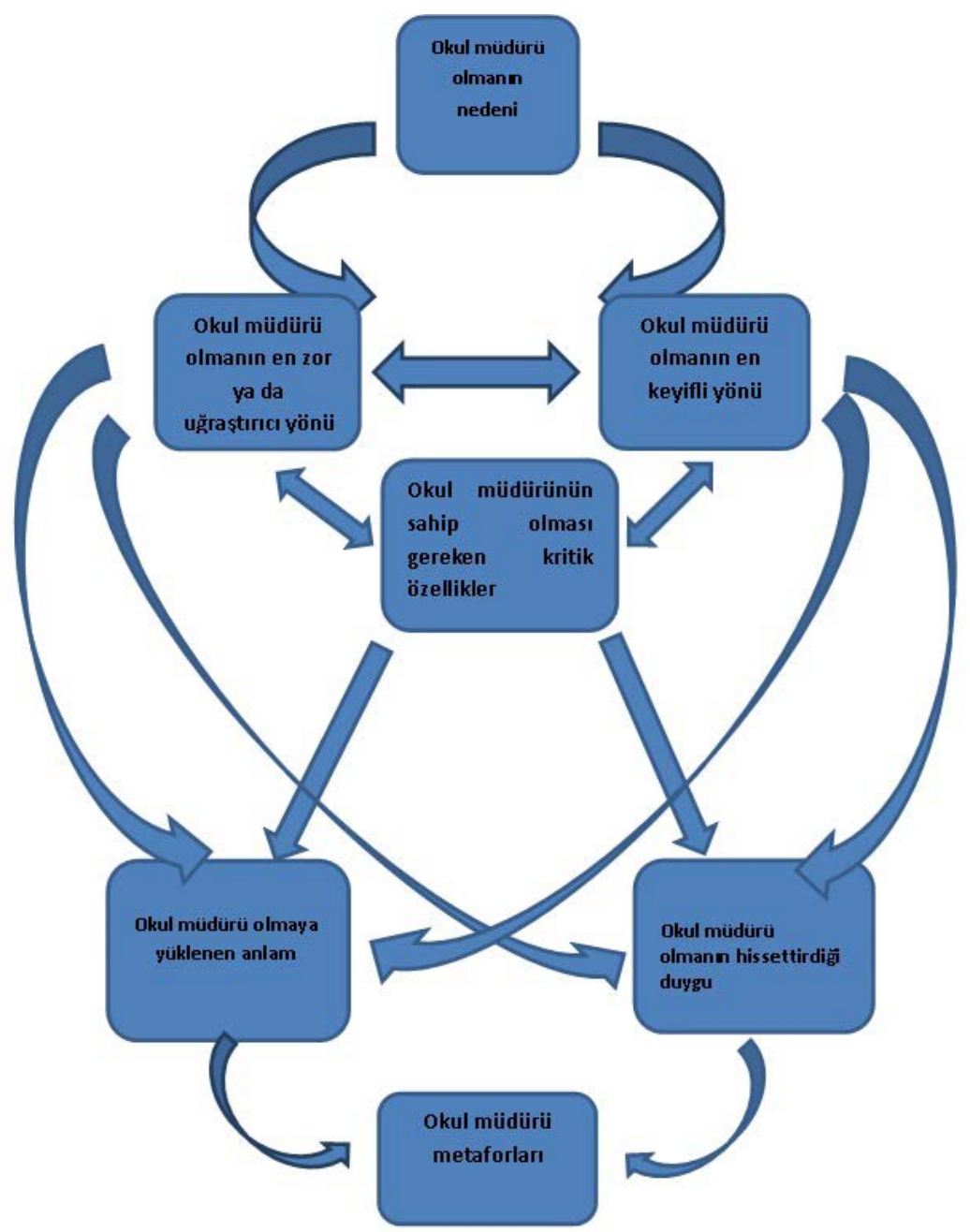

Şekil 1. Okul müdürï olmanın anlamı: Temalar

Şekil 1'de görüldüğ̈ü gibi, okul müdürü olmanın anlamı üzerine yöneticilerle yapılan görüssmelerden hareketle, okul müdürü olmann nedeni, okul müdürlüğ̈̈nün en zor ya da uğraştıncı yönü, okul müdürü olmanm en keyifli yö- 
nü, okul müdürünün sahip olması gereken kritik özellikler, okul müdürü olmaya yüklenen anlam, okul müdürü olmanın hissettirdiği duygu ve okul müdürü metaforları temaları oluşturulmuştur. Aşağıda her tema ayrı ayrı ele alınmıştır.

\section{Okul Müdürü Olma Nedenleri}

Katılımcıların okul müdürlügünü neden seçtiklerine ilişkin yaptıkları açıklamalardan hareketle elde edilen bulgular, Tablo 2'de, kategoriler ve alt kategoriler halinde sunulmuştur.

Tablo 2. Okul müdürü olma nedenleri

\begin{tabular}{ll}
\hline Neden türü & Nedenler \\
\hline \multirow{3}{*}{ İçsel güdüleyiciler } & Kendini hazır hissetme/ birikimini yansıtma \\
& Yönlendirme, liderlik yapma isteği \\
& Araştırmayı sevme \\
& Azimli olma \\
& Çalışmayı sevme \\
& İnsanların hayatına dokunma amacı \\
& İl merkezine atanma amacı \\
\hline & Daha geniş bir kitleye yararlı olma \\
& Okula, eğitime yararlı olma \\
& İçeme hizmet etme \\
& Daha nitelikli yönetilebileceğini gösterme \\
Etkili okula ve eğitime ilişkin & Değişim yapmak için yetki sahibi olma \\
amaçlar & Öğretmenlerin gelişimine katkı sağlama \\
& Yardımcllıtan sonra müdür olarak da hizmet vermek \\
& İyi bir eğitim ortamı sunma \\
\hline \multirow{2}{*}{ Dışsal güdüleyiciler } & Boş kadro/teklif gelmesi \\
& Çevrenin lider olarak görmesi \\
& Lisans döneminde yönlendirilme \\
\hline
\end{tabular}

Tablo 2'de görüldüğü gibi katılımcıları müdür olmaya yönelten lider olma isteği, çalışkanlık gibi bireyin kişisel yeterliklerine veya insana yararlı olmaya yönelik genel isteklere dayanan yedi neden, içsel güdüleyiciler; nitelikli eğitim için paydaşlara ya da topluma yararlı olma gibi amaçları gösteren sekiz neden, etkili okula ve eğitime ilişkin amaçlar; bireyin dışından bir etkiye dayanan üç neden dışsal güdüleyiciler kategorileri altında yer almaktadır. İçsel güdüleyiciler içindeki il merkezine atanma amacı bir katılımcı tarafından dile getirilmiş de olsa, özünde müdürlükle ilgisi olmayan bir nedeni gösterdiği için olumsuz bir neden olarak kabul edilebilir. Ancak çalısmaya katılan müdürlerin genel vurguları idealistçe bir yaklaşımı göstermektedir. Aşağıda müdürlerin görüşlerine örnek olabilecek alıntılar sunulmuştur. 
- "Ben öğretmenliğe başladım, atandım, ilk bir buçuk yıl doğu görevindeydim sonra ben x'liyim, kendi ilçeme geri döndüm. Çalışmayı gerçekten çok seviyorum. Bende zaman kavramı yok." (Çalışmayı sevme, Berna)

- "Belli bir süreden sonra öğretmen olarak çalıştıktan sonra da bu bizi tatmin etmiyor. Daha fazla şeyler yapmak istiyoruz. O okulu ben yöneteyim. Ben geliştireyim, gördüğüm eksikleri ben gidereyim." (Okula, eğitime yararl olma, Sare)

- “...okul müdürü olmamın nedeni bazı şeyleri değiştirebilmek için yetkiye sahip olmak gerekiyor... Diğer türlü bir çalışan olduğunuzda değiştirmek istediklerinizi değiştiremiyorsunuz ama okul müdürü olduğunuzda hem bürokratik engelleri aşma noktasında daha hızlı oluyor, fikirlerinizi iyi bir ekibiniz varsa aktarmanız kolay oluyor. O yüzden zorlu olan şeyleri değiştirme gücünüz oluyor." (Değişim yapmak için yetki sahibi olma, Selim)

- İki yöneticinin, mevcut yöneticilerin hatalı uygulamalarından hareketle, daha iyi bir yönetim sergileyebileceklerine olan güvenle yöneticiliğe yönelmiş olduklarını belirtmeleri de yine idealist bir yaklaşım olarak düşünülebilir. Aşağıda bu konudaki görüşlerden birine örnek verilmektedir.

- “...malumunuz, hocam, hiçbirimiz yöneticilik okumadık. Yani idareyle ilgili bir fakülte bitirmedik, sadece bazı derslerde yöneticilikle ilgili bilgiler verildi. Hepimiz aslında öğretmen çıkışlıyız. Bazı idarecilerin yapmış oldukları uygulamaları da etkiliyor insanı. 'Bak doğrusu bu şekilde yapılır.' bunu gösterebilmek çok önemli." (Daha nitelikli yönetilebileceğini gösterme, İlker)

\section{Okul Müdürü Olmanın En Zor Ya Da Uğraştırıcı Yönü}

Katılımcların, okul müdürü olmanın en zor ya da uğraştırıcı yönüne ilişkin görüşlerinden elde edilen bulgular, Tablo 3 'te kategoriler ve alt kategoriler olarak sunulmuştur. 
Tablo 3. Okul müdürlü̆̆̈̈nün en zor ya da uğraştırıcı yönü

\begin{tabular}{ll}
\hline Zorluk türü/zorluk alanı & Zorluklar \\
\hline & Finansman bulmak \\
& Temizlik personeli sağlamak \\
& Ödeneklerin/malzemelerin geç gelmesi \\
& Fiziksel koşulların yetersizliği \\
& Prosedürler/evrak işleri \\
& Önceki yönetimin eksiklerini tamamlamak \\
\hline \multirow{3}{*}{ Personel hizmetlerinin yönetimi } & Herkesin çözüm beklentisi \\
& Öğretimsel liderliğe zaman bulmak \\
& Öğretmenler arasındaki çatışmaları yönetmek \\
& Hatalı̈ğretmene geribildirim vermek \\
\hline \multirow{2}{*}{ Öğrenci-veli ilişkileri } & Maddi yetersizliği olan öğrencilere karşı roller \\
& Veliyi yönlendirmek \\
\hline \multirow{2}{*}{ Üst yönetimle ilişkiler } & Veliyle iletişim, veli talepleri \\
\hline & Merkeziyetçi yönetim \\
& Üst makamların gerçekçi olmayan beklentileri \\
\hline \multirow{2}{*}{ Okulun doğasından kaynaklı zorluklar } & Çoklu sorumluluk \\
& Hata kaldırmaması \\
& Olumsuz duyguları gizlemek \\
& Özel yaşama zaman ayırmak \\
\hline
\end{tabular}

Tablo 3'te görüldüğü gibi katılımcların okul müdürü olmanın en zor ya da uğraştırıcı yönüne ilişkin görüşlerinden elde edilen bulgular, beş kategori altında toplanmaktadır. Finansman bulmak, ödeneklerin/malzemelerin geç gelmesi, prosedürler/eorak işleri gibi eğitim ortamlarının eğitime hazır hale getirilmesine ve yapılan işlerin belgelenmesine yönelik altı zorluk, okul işletmesinin yönetimi kategorisini; herkesin çözüm beklentisi, öğretimsel liderliğe zaman bulmak gibi özellikle öğretmenlere yönelik sorumlulukları gösteren dört zorluk, personel hizmetlerinin yönetimi kategorisini; maddi yetersizliği olan öğrencilere karşı roller, veliyi yönlendirmek gibi öğrenci ve veliyle ilişkilere yönelik üç zorluk, öğrenci-veli ilişkileri kategorisini; merkeziyetçi yönetim üst makamların gerçekçi olmayan beklentileri şeklindeki okulun hiyerarşik olarak bağlı olduğu yönetim kademelerinin yetkisine ve kararlarma vurgu yapan iki zorluk, üst yönetimle ilişkiler kategorisini; çoklu sorumluluk, olumsuz duygular gizlemek gibi eğitimin ve okulun doğasından kaynaklanan dört zorluk ise okulun doğasından kaynaklı zorluklar kategorisini oluşturmaktadır.

Araştırmaya katılan okul müdürlerinin tümünün mutlaka dile getirdiği bir konu okul işletmesinin yönetimi kategorisindeki ilk üç zorluktan biri ya da birkaçı olmuştur. Okulun ihtiyacı olan kaynağın ya da malzemenin il/ilçe yönetiminden zamanında gönderilmemesi ya da hiç gönderilmemesi nedeniyle bu ihtiyacı karşılamak zorunda olmak, tüm resmi okul yöneticilerinin dile getirdiği bir konu olmuştur. Bazı yöneticiler bunu bir zorluk olarak 
ifade etmeden diğer konulara değinirken söylemişler, bazı yöneticiler de bu durumu ciddi ama "bir şekilde aştıkları " bir zorluk olarak ifade etmişlerdir. Özel okul müdürü olan katılımcı ise bu zorluğu ifade ederken, okulun kurucusuna ihtiyacı iletme zorluğu yaşadığını belirtmiştir.

Çok çarpıcı bir bulgu, devlet okulu müdürlerinin tedarik edilmesi gereken ihtiyaç olarak günlük yaşamı sürdürebilmek için gereken temizlik malzemesi, maske gibi çok temel ihtiyaçlar ya da temizlik personelini dile getirmesi; buna karşın özel okul müdürünün bilgisayar laboratuvarı gibi eğitsel ihtiyaçları dile getirmiş olmasıdır.

Aşağıda, okul müdürü olmanın en zor ya da uğraştırıcı yönü temasındaki alt kategorilere örnek olabilecek alıntılar sunulmuştur.

- "Ben bu okula geldim üçüncü haftamda hâlâ personelim yoktu. Yani okul açlacak diye gidiyorum. Şube müdürlerine soruyorum 'Müdürüm okulu açacağız ama temizlik personeli yok. Pandemi döneminde 'Hocam sen başının çaresine bak.' Yani ilk sözler bu şekilde; ellerinde olmadığ çalıştırmak da kolay değil. Yani onun ücreti var, SSK'si var, burada başına bir şey gelirse bunun sorumluluğunu kim alacak? Tamamen okul müdürü. Öyle durumlarda topu tamamen okul müdürüne atıyorlar." (Temizlik personeli sağlamak, Ekrem)

- "Maddi olarak ortaokullara yardım edilmemesi, her şeyi biz hallediyoruz. Biz şimdi bu pandemiden dolayı çok zorluk çektik. İşte hijyen maddeleri alınacak. Şimdi anca yeni yeni gelmeye başladı ama bu yeterli değil bizim okula. Mesela okulda badana olacak ama yok, kaynak yok. Parasal hiçbir şey yok. Şimdi yeni kişi sayısına göre okullarda şu kadarlık mal ya da dezenfektan, sabun. Ben de almışım onları zaten. Bize parasın verse biz kendimiz hallederiz." (Ödeneklerin/malzemelerin geç gelmesi, Fulya)

Resmi okullarda finansman yetersizlikleri böyle dile getirilirken özel okulda farklı boyutta dile getirilmiştir. Aşağıdaki alıntı farkı göstermektedir.

- "Mesela işte sistem laboratuvarları kurulması lazım, teknoloji sınıfları oluşturulması lazım. Bunların kağıt üstünde kalmaması lazım, gerçek anlamda bir laboratuvar olması lazım. Dolayısıyla maddi bir girişim olması gerekiyor da işte onu aşamıyoruz. Mesela orada artık kurucunun ne kadar yatırım yapacağına bağlı." (Finansman bulma, Selim) 
- "Yani senin sıkıntın varken başkasını dinlemek. Evet hocam ben çok sorunlarım olduğu zaman olabilir, iç dünyamda her zaman olmuyor ama bunu kesinlikle karşımdaki öğretmene veliye çocuğa yansıtmamak durumundayım. Onun için de kendimi çok çok zorladığım zamanlar oldu." (Olumsuz duyguları gizlemek, Ayhan)

\section{Okul Müdürü Olmanın En Keyif Verici Yönü}

Katılımcıların, okul müdürü olmanın en keyif verici yönüne ilişkin görüşlerinden elde edilen bulgular, Tablo 4'te kategoriler ve alt kategoriler olarak sunulmuştur.

Tablo 4. Okul müdürü olmanın en keyif verici yönü

\begin{tabular}{|c|c|}
\hline Keyif verme konusu & Keyif verici yön \\
\hline Sorun çözme/mutlu etme & $\begin{array}{l}\text { Çabanın sonuçlarını görmek (iç paydaş mutluluğu) } \\
\text { mutluluğu)mutluluğu } \\
\text { Yetkiyi çözüm için kullanmak } \\
\text { Beklentileri karşılamak } \\
\text { Öğretmenin başarısına katkıda bulunmak } \\
24 \text { saat çalışmak/hizmet etme } \\
\end{array}$ \\
\hline Öğrenci başarısı ve gelişimi & $\begin{array}{l}\text { Öğrencilerin sınav başarısı } \\
\text { Öğrencilerin değerleri kazanmış olduğunu görmek } \\
\text { Mezuniyet anları } \\
\text { Öğrencileri etkinliklerde izlemek }\end{array}$ \\
\hline Ekip çalışması ve iletişim & $\begin{array}{l}\text { Ekip çalışmasının başarıya ulaşması } \\
\text { Ekibi sorunsuz yönetmek } \\
\text { Okul içinde dolaşıp iletişim kurmak }\end{array}$ \\
\hline Olumlu geribildirim & $\begin{array}{l}\text { Olumlu veli, öğretmen geribildirimleri } \\
\text { Öğrencinin sevgi göstermesi } \\
\text { Çevrenin güven duyması } \\
\text { Toplum gözündeki saygınlık }\end{array}$ \\
\hline
\end{tabular}

Tablo 4'te görüldüğü gibi katılımclların okul müdürü olmanın en keyif verici yönüne ilişkin görüşlerinden elde edilen bulgular, dört kategori altında toplanmaktadır. Çabanın sonuçlarmı görmek (iç paydaş mutluluğu), beklentileri karşılamak, öğretmenin başarısına katkıda bulunmak gibi paydaşlara hizmet etmeyi, onları mutlu etmeyi vurgulayan beş keyif verici yön sorun çözme/mutlu etme kategorisini; öğrencinin sevgi göstermesi, öğrencileri etkinliklerde izlemek gibi öğrencilerin gelişme göstermesine vurgu yapan dört keyif verici yön öğrenci başarısı ve gelişimi kategorisini; ekip çalışmasının başarıya ulaşması, okul içinde dolaşı iletişim kurmak gibi iletişime dayalı çalışmayı vurgulayan üç keyif verici yön, ekip çalışması ve iletişim kategorisini; olumlu veli, öğretmen 
geribildirimleri, öğrencinin sevgi göstermesi gibi dişsal geribildirime vurgu yapan dört keyif verici yön ise olumlu geribildirim kategorisini oluşturmaktadır.

Katılımcılar için okul müdürlüğünün keyif verici yönü teması altındaki kategori ve alt kategoriler incelendiğinde genel olarak, yapılan çalışmaların ve gösterilen çabanın olumlu sonuçlarını görmenin keyif verici olduğu anlaşılmaktadır. Bazı okul müdürlerinin, okul müdürlüğünün zor olduğunu dile getirdikten sonra yine de zorlukları aşmaya çalıştıklarını anlatıp sonra keyif verici yönlere iliş̧kin görüş bildirdikleri gözlemlenmiştir. Aşağıda, okul müdürü olmanın en keyif verici yönü temasındaki alt kategorilere örnek olabilecek alıntılar sunulmuştur.

- "Aynı zamanda öğrenciler için de bu geçerli. Mesela yurtdışına gittik... Romanya'ya, Polanya'ya gittik. 12 öğrencinin o mutlulukları daha da farklı bir duygu yani... Sinemaya giden öğrenci var, hamburger yiyen öğrenci var, sıcak çikolata içen öğrenciler var. Bunlar hep mutluluğunuzu artırıyor."(Çabanın sonuçlarını görmek-iç paydaş mutluluğu, Cem)

- “Okul müdürü olmak hiç de kolay değil. Öncelikle onu söyleyeyim, göründüğünden daha zormuş... hem öğrenciler mutlu oldu, birlikte bir çalışma yaptık. Arkadaşlarımla birlikte bir çalışma yaptık, hep birlikte ekip olarak çalışıp güzel bir şey gerçekleştirdiğimiz, başardığımız zaman daha mutlu oluyorum." (Ekip çalışmasını başarıya ulaşması, Sare)

- "Yani çocuklara bir ana baba gibi oluyorsun. Onların sevgisini gözlerinden anliyorsun. Zaten nasil olursan ol yani erkeksin, bayansin, uzun boylusun, kısa boylusun fark etmez. Çocuk için ilkokul öğretmeni çok önemlidir ama müdürlük hayatımda da hep güzel şeyler görmek. Dışarı çıktığım zaman -çocukları şu an uzaklaştırıyoruz, temas yok diyerekten ama- gelip sana sarıldığı zaman her şey bitti zaten. Görüyorsun onu." (Öğrencinin sevgi göstermesi, İlker)

- "Toplum nazarında hani okul müdürü olarak farklı bakılıyorsun... Yönetici oldum onun bir artısı, olabilir. En keyifli yönü olarak." (Toplum gözündeki sayginlı, Ekrem)

Katılımcların tümünün okul müdürü olmaktan keyif aldıkları, özellikle öğrenci, veli ve öğretmenleri mutlu etmenin, onlardan olumlu geribildirimler almanın okul müdürleri için çok önemli olduğu anlaşılmaktadır. Hem bu tema altında hem de başka sorulara yanıt verirken çoğu okul müdürünün öğretmenlerle birlikte çalışmayı, ekip çalışmasını vurguladığı da araştırmacının dikkatini çekmiştir. 


\section{Okul Müdürünün Sahip Olması Gereken Kritik Özellikler}

Katılımcların okul müdürünün sahip olması gereken kritik özelliklere ilişkin yaptıkları açıklamalardan hareketle elde edilen bulgular Tablo 5 'te kategoriler ve alt kategoriler halinde sunulmuştur.

\section{Tablo 5. Okul müdürünün sahip olması gereken kritik özellikler}

\begin{tabular}{|c|c|}
\hline Yeterlik türü & Yeterlik \\
\hline \multirow{11}{*}{ Bireysel ve psikolojik özellikler } & Yeniliğe/ değişime açıklık \\
\hline & Adaletli/ objektif olma \\
\hline & Güven verici olma/Dürüst olma \\
\hline & Bakımlı olma \\
\hline & Yöneticiliği sevme/ okula mutlu gelme \\
\hline & Sorumluluk sahibi olma \\
\hline & İnsanlara saygilı olma \\
\hline & Eleştiriye açık olma \\
\hline & Strese karşı dayanıklı olma \\
\hline & Soğukkanlı olma \\
\hline & Alçakgönüllü olma \\
\hline \multirow{7}{*}{ İletişim yeterlikleri } & Dinleme/insan ilişkilerinde yeterli olma \\
\hline & Bireysel farklılıkları/ ihtiyaçları dikkate alma \\
\hline & Çevreyi ve iç paydaşları tanıma \\
\hline & Konuşma becerisi/açık sözlü olma \\
\hline & Kişisel sorunları yansıtmama/ güler yüzlü olma \\
\hline & Üniversiteyle bağ kurabilme \\
\hline & Önyargısız/empatik olma \\
\hline \multirow{11}{*}{ Yönetsel yeterlikler } & Odasından çıkma/ yalnız emirle yönetmeme \\
\hline & Öğretim lideri/ yenilik önderi olma \\
\hline & Ekiple çalışma/ yetki devretme \\
\hline & Yönetimi bilme \\
\hline & Planlı çalışma \\
\hline & Örnek olma \\
\hline & Uzmanlık gücünü kullanma \\
\hline & Katılımcı yönetim sergileme \\
\hline & İnsan kaynaklarını yönetebilme \\
\hline & Sorunu ertelememe \\
\hline & Örgütleme yapabilme \\
\hline \multirow{6}{*}{ Teknik yeterlikler } & Psikolojiyi bilme \\
\hline & Sınav sürecini bilme \\
\hline & Mali konularda bilgili olma \\
\hline & Okul türüne uygun branştan gelme \\
\hline & Mevzuat bilgisi/ resmi yazışmalan bilme \\
\hline & Teknolojiyi kullanma/dijital beceriler \\
\hline
\end{tabular}

Tablo 5'te görüldügü gibi katılımcıların okul müdürünün sahip olması gereken kritik özelliklere ilişkin görüşlerinden elde edilen bulgular dört kategori altında toplanmaktadır. Okul müdüründe olması gereken, yenili- 
ğeldeğişime açıklık, adaletli/ objektif olma, güven verici /dürüst olma gibi temel insani değerler ile strese karşı dayankkl olma, soğukkanlı olma gibi okul dışındaki iş yerlerinde de gerekli olan bireysel özellikleri anlatan on bir özellik bireysel ve psikolojik özellikler kategorisini oluşturmaktadır. Bireysel farkllıklarıl ihtiyaçları dikkate alma, konuşma becerisil açık sözlü olma, önyargısız/ empatik olma gibi doğrudan etkili iletişimin gerekliliği olan yedi özellik iletişim yeterlikleri kategorisinde; ekiple çalışmal yetki devretme, katılımo yönetim sergileme, insan kaynakların yönetebilme gibi yönetimle ilgili yeterlikleri gösteren on bir özellik yönetsel yeterlikler kategorisinde; psikolojiyi bilme, mali konularda bilgili olma, mevzuat bilgisi/resmi yazışmalar bilme gibi bir konunun temeli olabilecek bilgiye sahip olmayı anlatan altı özellik teknik yeterlikler kategorisinde yer almıştır. Aşağıda okul müdürünün sahip olması gereken kritik özelliklere ilişkin katılımcıların görüşlerine örnek olabilecek alıntılara yer verilmiştir.

- "Eşitlik ve adalet hocam, söylemde değil, eylemde de eşitlik ve adalet; örneğin iki gün önce öğretmenler kurul toplantısı yaptık, bütün okullarımızda yapıldı. Burada cümlelerin arasında eşit olalım, adaletli olalım, demek yerine ...bunu uygulamalarda beraber çalıştığınız insanlara o hissi veriyor olmak adil olduğunu göstermek. 'Evet müdürü sevmesem de adildir.' denmesi. Bu cümle benim için çok önemlidir." (Adaletli/objektif olma, Ekin)

- "İnsan beklentilerini, insan davranışlarını, insanların ihtiyaçlarını anlayabilmeli ve karşısındaki insanlarla görüşürken bunları mutlaka dikkate almalı. Bu bir öğrenci, bir veli de olsa bir öğretmen ya da herhangi bir kişi de olsa bunu göz ardı etmemeli. Onun ihtiyacına önem verdiğimizi göstermeliyiz diye düşünüyorum. Öncelikle insan ilişkilerinin iyi olması gerekir." (Bireysel farkllhklarıl ihtiyaçlar dikkate alma, Sare)

- "Yani okul müdürü deyince odasında oturan işte öğretmenlere şunu yapın veya hizmetli personele, şunu yapın veya okul aile birliğine veya velilere şunları bunları yapın şeklinde değil de gerektiğinde veli olabilmek, gerektiğinde öğretmen olabilmek, gerektiğinde hizmetli personel. Mesela dün sıralarımız geldi sırtımızda çektik onları. Yani şey olarak bakıyorum ben bütün olabilmek yani." (Odasından çıkmal yalnız emirle yönetmeme, Osman)

- "Bir defa yönetimle ilgili bilgi sahibi olması lazım. Her alanda sadece okul yönetimi değil, yönetimin temelden gelişimi hakkında, okul yöne- 
timi ve özelinde, bir de okulun nasıl yönetileceği hakkında genel bilgi sahibi olmamız lazım." (Yönetimi bilme, Ayhan)

- "Bulunduğu çevreyi gerçekten, hitap ettiği kitleyi çok iyi tanımalı bence öncelikle. Diyelim ki bir okuldasınız; okuldaki öğrencileri çok iyi tanımanız lazım, velileri çok iyi tanımanız lazım, öğretmenlerinizi çok iyi tanımanız lazım, bütün özelliklerini bilmeniz lazım. Bunları bildikten sonra zaten yol haritanız kendiliğinden ortaya çıkıyor. Çevreyi tanımanız lazım." (Çevreyi ve iç paydaşlan tanıma, Yavuz)

\section{Okul Müdürü Olmaya Yüklenen Anlam}

Katılımcıların okul müdürlüğüne yükledikleri anlama ilişkin yaptıkları açıklamalardan hareketle elde edilen bulgular Tablo $6^{\prime}$ da kategoriler ve alt kategoriler halinde sunulmuştur.

Tablo 6. Okul müdürü olmaya yüklenen anlam

\begin{tabular}{ll}
\hline Yükleme türü & Anlam \\
\hline \multirow{4}{*}{ Müdürün kim olduğuna yönelik yükleme } & Önder \\
& Temsilci (MEB'i, öğrencileri, öğretmenleri, mahalleyi) \\
& Okulun tüm süreçlerini yöneten kişi \\
& Karar mercii \\
& Özümüz öğretmen \\
\hline & Okulun her şeyinden sorumlu olma \\
& Başkalarına yararlı olma \\
& Amaçlara uygun öğrenci yetiştirme \\
Müdürün rollerine ilişskin yükleme & İnsanların sorunların çözme \\
& Aile reisliği gibi ihtiyaçları karşlama \\
& Öğretmenleri destekleme \\
\hline \multirow{2}{*}{ Müdürün rollerini nasıl yerine getirdiğine } & İnsanları dinleyerek \\
iliş̧in yükleme & Adaletli davranarak \\
& Zaman sinırı olmadan çalı̧arak \\
& Tatlı sert yöneterek \\
\hline \multirow{2}{*}{ Müdür olmanın kendisine etkisine } & Yaşama sebebim \\
yönelik yükleme & Sayginlık \\
\hline
\end{tabular}

Tablo 6'da görüldüğü gibi katılımcıların müdür olmaya nasıl bir anlam yükledikleriyle ilgili bulgular dört kategori altında toplanmaktadır. Müdürlük makamındaki kişinin önder, temsilci ya da özünde öğretmen olan kişi olmas1 gibi kim olduğuna işaret eden beş anlam, müdürün kim olduğuna yönelik yükleme; başkalarnna yararl olma, insanlarm sorunlarm çözme, öğretmenleri destekleme gibi ne yaptığına işaret eden altı anlam, müdürün rollerine ilişkin yükleme; insanları dinleyerek, tatl sert yöneterek gibi nasıl çalışması gerektiğine 
ilişkin alt anlam müdürün rollerini nasıl yerine getirdiğine ilişkin yükleme; saygınlık gibi müdür olmanın bireyin kendisine katkısına ilişkin üç anlam da müdür olmanın kendisine etkisine yönelik yükleme kategorilerini oluşturmaktadır. Aşağıda, okul müdürü olmanın katılımcılar için ne ifade ettiğine ilişkin görüşlerinden örnek olabilecek alıntılar sunulmuştur.

- “Okul müdürü eşittir çok büyük bir sorumluluk altındasınız. Her şeyden sorumlu olmak diyorum." (Okulun her şeyinden sorumlu olma, Fuat)

- “...burada olmaktan dolayı acaba ne kadar öğrenci üniversiteyi kazanmış ne kadar öğrenci gerçekten de mesleğinde başarılı olmuş üniversite kazanmak mutlaka o da çok önemli, eğitim alması, ama iyi bir demirci iyi bir marangoz ve çevresinde gerçekten de faydalı olmuş iyi insanlar yetiştirdiğim anda, devletini seven özellikle devletini seven ben bu konuda daha çok şey yapıyorum, devletini, milletini seven bireylerin yetişmesini istiyorum. Yani benim önceliğim bu." (Amaçlara uygun öğrenci yetiştirme, Osman)

- “Ben okul müdürlüğünü çok seviyorum kurallara uymayı seviyorum ama şimdiki şeylerde göremiyorum ben yani. Hani eski toprak derler ya bizim şimdiki yeni nesil maalesef her şey yazı çizi sanıyorlar. Hayır bence idarecilik demek otorite demek, disiplin demek, kural demek aş1rıya kaçmamak şartiyla. Tatlı sert oynayarak bu işleri yürütmektir" (Tatlı sert yöneterek, Fulya)

- "Kendimi gerçekleştirdiğime inanıyorum, ben. Öyle bir anlamı var, kendimi yapmak istediğim şey buydu." (Kendini gerçekleştirme, Ayhan)

Okul müdürlüğüne yüklenen anlam teması altında ön plana çıan açılamalar ve kategoriler müdürün rollerine ve bu rolleri yerine getirirken nasıl çalıştı̆̆ına/çalışması gerektiğine ilişkindir. Kendisini özünde öğretmen olarak tanımlama, başka alt problemlerde de karşımıza çıkmıştır. Bunu, müdürlüğü anlamlandırmada olumsuz bir duruş olarak en azından okul müdürlüğ̈nün meslekleşmemesinin göstergesi olarak düşünmek mümkündür.

\section{Okul Müdürü Olmanın Hissettirdiği Duygu}

Katılımcların okul müdürü olduklarını düşündüklerinde yaşadıkları duyguya ilişkin bulgular Tablo 7'de kategori ve alt kategoriler olarak sunulmuştur. 
Tablo 6. Okul müdürü olmanın hissettirdiği duygu

\begin{tabular}{ll}
\hline Duygu niteliği & Duygu \\
\hline & Gurur \\
& Mutluluk \\
& Sorumluluk \\
& Sevgi \\
Olumlu & Heyecan \\
& Babalik duygusu \\
& İyi hissediyorum \\
& Haz, manevi doyum \\
& Kendine güven \\
\hline \multirow{2}{*}{ Olumsuz } & Özel bir duygu hissetmiyorum/Öğretmenim \\
\hline
\end{tabular}

Tablo 7'de görüldüğğ gibi katılımcıların okul müdürü olmaktan dolayı yaşadıkları duyguya ilişkin bulgular iki kategori altında toplanmaktadır. Katılımcılarla yapılan görüşmelerde okul müdürü olmaktan hoşnut oldukları ve bunu genel olarak olumlu duygularla ifade ettikleri görülmüştür. Okul müdürü olmanin hissettirdiği gurur, sorumluluk, kendine güven gibi dokuz duygu olumlu; özel bir duygu hissetmiyorum, bazen sorguluyorum şeklindeki iki yargıyla verilen durum, olumsuz kategorilerini oluşturmaktadır. Aşağıda, okul müdürü olmanın katılımcılara yaşattığı duyguya ilişkin görüşlerinden örnek olabilecek alıntılar sunulmuştur.

- "Yani beynimde neyi uyandırdığını şöyle bir sorguladım, öğle arası geldi herhalde, yemek yemek kadar beni mutlu ediyor herhalde. Öyle tahmin ediyorum." (Mutluluk, Ekin)

- "Büyük bir sorumluluk hissediyorum inanılmaz derecede... hem çocuklar adına hem personel adına hem de kendi adıma. Çünkü bir yeri temsil etmek kolay bir şey değil. Bu çok önemli bir şey. Benim okulumla ilgili bir çalışma yaptığımda ya da öğretmenlerimle ilgili, hiç kimse işte Berna yaptı demiyor. Okulumuzun adı geçiyor, işte bu okul bunu yaptı, diyor. O yüzden öncelikle büyük bir sorumluluk hissediyorum." (Sorumluluk duygusu, Berna)

- "Okulu seviyorum bence sevmek çok önemli burada... Gerçekten çok yoğunuz, buraya sabah 8.30'da gelip akşam 17.30'a kadar okulda kalmak, daha sonra eve gidip yemek hazırlamak, ev işleriyle uğraşmak, gerçekten sevilmese okul müdürlüğü, asla ve asla çekilecek bir görev değil diyorum." (Sevgi, Fulya) 
Yapılan görüşmelerde katılımcıların okul müdürlüğünü, sorumluluğu fazla ve zaman zaman zor bir görev olarak gördükleri anlaşılmıştır. Ancak müdürlüğü sevdiklerini ve genel olarak müdür olmanın kendilerine olumlu duygular yaşattığını ifade eden pek çok açıklamaları olmuştur. İki yönetici olumlu duygular yanında olumsuz olarak sınıflandırdığımız ifadelere de yer vermiştir. Bunlardan biri, öğretmenliği sevdiğini ve müdür olmanın özel bir duygu hissettirmediğini, kendisini öğretmen olarak gördüğünü belirtirken diğer müdür, kendini iyi hissettirdiğini ama bazen yoğun iş yükü ve uzun çalışma saatleri nedeniyle durumunu sorguladığını aşağıdaki sözlerle anlatmıştır.

- “...zaman zaman sıkıntılarla karşılaşınca niye okul müdürü oldum diye böyle kendini sorgulayabiliyorsun yani; çünkü öğretmen olup tatil yapmak, dersini anlatıp çıkmak varken böyle şeylere ne gerek vardı gibi. Zaten dışarıdan da zaman zaman bu tip şeyler duyabiliyoruz... kaç yıl daha yaşayacaksın, gece gündüz koşturuyorsun, biraz kendine vakit ayır, gibi cümleler de duymuyor değiliz." (Bazen sorguluyorum, Fırat)

\section{Okul Müdürü Metaforları}

Katılımcıların okul müdürünün neye benzediğiyle ilgili olarak ürettikleri metaforlar ve bu metaforların benzetme yönü Tablo 8' de sunulmuştur.

Tablo 8. Okul müdürü metaforlarn

\begin{tabular}{|c|c|}
\hline Benzetme yönü & Metafor ve açıklaması \\
\hline Çalışkanlık/Çoklu sorumluluk & $\begin{array}{l}\text { Çok kollu, çok gözlü bir cihaz: Bütün işleri koordine edebilmeli, } \\
\text { hepsinden haberdar olabilme, hepsini yapabilmeli. (Berna) } \\
\text { Ahtapot: Her şeyden anlamal, her şeyle ilgilenmeli. (Sare) } \\
\text { Karınca: Boş durmayan hep çalışan bir canll. (Ayhan) }\end{array}$ \\
\hline Hoşgörü, sakinlik & $\begin{array}{l}\text { Pamuk şeker: Yumuşak, tatlı. Katı kuralcı olmayan, sinirlenmeyen. } \\
\text { (Osman) } \\
\text { Masmavi, dalgasız duru, engin bir deniz: Rüzgarın etkisiyle hafif } \\
\text { dalgalanabilen güneşin parlaklı̆̆ııı yansıtan, sakin. (Fulya) }\end{array}$ \\
\hline $\begin{array}{l}\text { Dayanıklılık ve herkese yararlılık, } \\
\text { herkesi kucaklama }\end{array}$ & $\begin{array}{l}\text { Heybetli bir ağaç (Kayın ağacı gibi): Güven verici să̆lam, gölgesin- } \\
\text { de herkes dinlenip yola devam eder. (Selim) } \\
\text { Ahtapot: Herkesi kucaklamalı. (Cem) } \\
\text { Sürekli bir enerji kaynağı: Çevreye enerji verir. (Canan) }\end{array}$ \\
\hline Demokratik değerler & $\begin{array}{l}\text { Adalet heykeli: Herkese adaletli davranır. (Ekin) } \\
\text { Takım kaptanı: Takım oyuncularıla eşit koşullarda görev yapar, aynı } \\
\text { zamanda hedefe yönlendirir.(Fırat) }\end{array}$ \\
\hline Yöneticilik, liderlik & $\begin{array}{l}\text { Kaptan : Gemiyi hedefe ulaştırmak gibi, müdür okulu hedefe ulaştırmaya } \\
\text { çalışmalı. (Fuat) } \\
\text { Arabanın motoru: Motor çalışmazsa araba gitmez. (Illker) }\end{array}$ \\
\hline
\end{tabular}


Araştırmaya katılan 14 katılımcının 12'si okul müdürüyle ilgili metafor üretmiştir. Üretilen metaforlar ve onlara ait benzetme yönü Tablo 8'de beş kategori olarak yer almaktadır. Okul müdürünün sürekli çalışan ya da çok çeşitli ve fazla sorumluluğu olduğuna işaret eden üç metafor; hoşgörülü ya da sakin olduğuna işaret eden iki metafor; dayanıklılığına, herkese ulaşmasına ve herkese yarar sağlamasına işaret eden üç metafor; adaletli olmasına ya da takımına diğerleriyle eşit koşullarda katkı sağlayan bir takım oyuncusu olmasına işaret eden iki metafor; grubun var olması için kritik pozisyonda bulunan lider ya da yöneticiye işaret eden üç metafor üretilmiştir. Üretilen metaforların çoğunun olumlu olması, katılımcların müdürlüğü seçme nedenleriyle ve okul müdürü olmayı keyifli bulmalarıyla da tutarlılık göstermektedir. Yöneticinin aşırı ve çoklu sorumluluğu olmasını yansıtan, çok kollu, çok gözlü bir cihaz ile ahtapot metaforları olumsuz algılanabilecek metaforlardır.

\section{Tartışma ve sonuç}

Okul müdürlüğünün anlamını bu mesleği deneyimleyen okul müdürlerinin görüşlerine dayanarak betimlemeyi amaçlayan bu çalışmada 14 okul müdürüyle görüşülmüştür. Araştırma verilerinden elde edilen bulgular yedi alt probleme göre yedi tema altında toplanmıştır. Birincisi katılımcıların müdürlüğü seçme nedenleridir. Katılımcllar, okul müdürlüğünü seçme nedenlerini kendilerindeki çalışmayı sevme ya da liderlik yapma isteği gibi içsel güdüleyicilerle ya da yarar ve hizmet odaklı ve "etkili okula ve eğitime ilişkin amaçlar"la açıklamışlardır. Dışsal güdüleyicilerden söz eden müdürler olsa da bu dişsal güdüleyiciler yalnızca içsel güdüleyicileri biraz daha pekiştiren nedenler durumundadır. Bu anlamda müdürlüğün seçilme nedenleri okullar ve mesleki açıdan sevindiricidir. Araştırmamızın bu bulgusu alanyazındaki, öğretmenlerin yöneticiliği seçme nedenlerine ilişkin; ideallerini gerçekleştirmek, okulda daha sağlam ve kalıcı görev yapmak, kendilerini yeterli görmek (Yeşilkaya; 2007); okulu etkin ve örnek okul haline getirmek (Köse; 2008), deneyimlerini uygulamaya aktarmak ve yararlı olmak (Erginer ve Köse, 2012) bulgularıla desteklenmektedir.

İkinci olarak okul müdürleri, müdürlüğün en zor ya da uğraştırıcı yönü konusunda "okul işletmesinin yönetimi" kapsamındaki konuları vurgulamışlardır. Resmi okul müdürleri, okulun eğitim öğretime hazır olması için 
asgari düzeyde gereken ihtiyaçları sağlama sorunlarını vurgularken, özel okul müdürünün sistem laboratuvarı, teknoloji dersliği gibi eğitimin niteliğini artırmaya dönük ihtiyaçları vurguladığı görülmüştür. OECD (2020) raporuna göre, Türkiye, resmi ve özel okullardaki eğitim ortamları arasında en büyük farka sahip ülkelerden biridir. Araştırmamızın bu bulgusunun OECD’nin ortaya koyduğu bu gerçekle ilişkili olduğu söylenebilir. Bulgularımıza göre resmi okul yöneticilerinin en önemli zorlukları ağırlıklı olarak, finansman sağlamak, temizlik personeli bulmak, geç gelen ödenekler gibi konulardır. Bunun yanında, önceki yönetimin eksiklerini tamamlamak, evrak işleri gibi diğer işletme sorunları yanında, çatışma çözmek gibi personel hizmetlerinin yönetimine, veliyi yönlendirmek gibi öğrenci-veli ilişkilerinin yönetimine, üst yönetimin gerçekçi olmayan beklentileri gibi üst yönetimle ilişkilere ve yapılan işin hata kaldırmaması gibi okulun/eğitimin doğasına ilişkin zorluklar dile getirilmiştir. Bazı müdürler, bu zorluklardan kaynak ve temizlik personeli bulmayla ilgili olanları ciddi bir sıkıntı olarak ele almış, bazı yöneticiler velilerle ilgili sıkıntıları ciddi bir zorluk olarak dile getirmiştir. Hem resmi okullarda hem özel okulda öğretmene geribildirim verme ya da çatışma yönetmenin yaygın olmasa da müdürler açısından zorluk ya da uğraştırıcı bir durum olarak algılandığı belirlenmiştir.

Müdür olmanın zorluğuyla ilgili konuşurken müdürlerin, evrak ve mevzuata dayanan işleri kolay ama zaman alıcı bulduğu, eğitim öğretimle ilgili işleri kolay, zevkli ama zaman bulunamayan konular olarak gördüğ̈̈; öğretimsel liderliğe zaman bulmanın bazı müdürler için ciddi bir zorluk olduğu anlaşılmıştır. Bu konuda, her zaman zor olmasa da çok fazla enerji ve zaman alan konu, kaynak, malzeme ve personel bulma konusudur. Bu bulgu, alanyazındaki, okulların kaynaklarının yetersiz olduğu ve müdürlerin sorunları arasında okula kaynak bulmanın olduğuyla ilgili (Çopur ve Yengin Sarpkaya, 2020; Demirtaş, ve Özer, 2013; Eğitim-Bir Sen, 2019; Gümüşeli, 2001; Karakütük ve Özdoğan Özbal, 2019; Kılıç, 2020) bulgularla koşutluk göstermektedir. Eğitim kurumlarının finansmanının kamu kaynaklarından karşılanma oranı OECD ortalaması olarak \%91, Türkiye'de ise \%80'dir (OECD, 2017). Finansmanın, okul sistemlerinin eğitim kaynakları elde etmesini sağlayan bir mekanizma olduğu ve bir yeterlik eşiğini yakalamasının çıktılar açısından önemli olduğu kabul edildiğinden (Deloitte Access Economics, 2016) araştırmamızın bu bulgusu ayrıca önemli görünmektedir. 
Alanyazındaki çalışmalarda başarılı bir okul müdüründe olması gereken en önemli liderlik özelliklerinden ikincisinin öğretimsel liderlik olduğu (Duran ve Cemaloğlu, 2020), öğretimsel liderliğin öğretimi ve öğretmeni geliştirme boyutunun öğretmenin örgütsel vatandaşlık davranışını etkilediği (Ünal ve Çelik, 2013) belirlenmiştir. Diğer yandan eğitim yöneticileri tarafından belirlenen sorunların en önemlilerinden birinin, öğretmenin kendini yenilememesi olduğu (Karakütük ve Özdoğan Özbal; 2019) dikkate alınd1ğında; ama 21. yüzyılda müdürlerin en önemli görevlerinden birinin öğretimsel liderlik olduğu (Aksoyalp, 2010) da düşünüldügünde yaptığımız araştırmada müdürlerin öğretimsel liderliğe zaman bulmada zorluk yaşadığının belirlenmesinin, -genelleme yapılamasa da- milli eğitim sisteminin amaçlara ulaşması konusunda kaygılandırıcı olduğu söylenebilir. Ancak alanyazındaki, gelişmekte olan ülkelerde müdürlerin öğretimsel liderlik yapmadıkları bulgusu (Oplatka, 2004), araştırmamızın bulgusunu destekler niteliktedir.

Araştırmanın üçüncü alt problemi müdür olmanın en keyif verici yönüne ilişkindir. En keyif verici yönle ilgili bulgular genel olarak, yapılan çalışmaların başarıya ulaştı̆̆ını görme; öğrenci veli ve öğretmenlerin mutlu olduğunu görme ve olumlu geribildirim almaya dayanmaktadır. Bu alt problemden elde edilen bulgularla birinci alt problemden (okul müdürü olmanın nedeni) elde edilen bulgular oldukça tutarlıdır. Katılımcıları müdür olmaya yönelten genel güdü çalışmak, hizmet etmek, yararlı olmaktır. Müdür olmanın en keyifli yönü de genel olarak, yararlı olduğunu görmek biçiminde özetlenebilir. Bass'a (2004) göre müdürlüğe başlamadaki en önemli güdüleyici etmenlerden biri öğrenciler ve diğer insanlar üzerindeki olumlu etki yapma arzusudur. Newton ve Wallin'in (2013) araştırma bulgularına göre de çoğu müdür için mesleğin en keyifli yönü öğrencilerle etkileşimdir. Müdürler, öğrenci mutluluğundan söz ederken öğrencilerin akademik başarıları dışındaki deneyimlerine ve kazanımlarına oldukça sık vurgu yapmışlardır. Yirmi birinci yüzyıl becerileri içinde sayılan yumuşak beceriler diye de ifade edilen bilişsel olmayan becerilerin eğitimle geliştirilebilir olduğu kabul edildiğinden (Deloitte Access Economics, 2016) yöneticilerin bu vurgusu önemlidir. Katılımcılar, müdür olmanın keyifli yönlerini dile getirirken, "gerçekten zor ama seviyorum", "gerçekten zor ama mutluyum" gibi ifadeler kullanmışlardır. 
Araştırmanın dördüncü alt problemi, okul müdüründe bulunması gereken kritik özelliklerle ilgilidir. Bu konuda elde edilen bulgular birkaç başlıkta özetlenebilir. Bütün katılımcılar, genel olarak bir insanda bulunması gereken adaletli olmak, insanlara saygılı olmak gibi bireysel özellikleri vurgulamıştır. Araştırmada bunun dışında ön plana çıan bulgu, tüm katılımcıların iletişim yeterlikleriyle ilgili çeşitli özellikleri vurgulamış olmasıdır. Bu bulgu alanyazındaki araştırma bulgularıyla örtüşmektedir (Demirtaş, ve Özer, 2013; Duran ve Cemaloğlu, 2020; Gümüşeli, 2001; Gürbüz vd., 2013; Turan, Yıldırım ve Aydoğdu, 2012). İletişim yeterliğine ilişkin açılamalar diğer alt problemlere ilişkin soruları yanıtlarken de sıklıkla vurgulanmıştır. Ayrıca, yönetsel yeterliklerden ekip çalışması ve okul müdürünün odasında durmaması gerektiği ve yalnız makam gücüne dayanarak emirlerle yönetmemesi gerektiği de dikkati çekecek kadar çok vurgulanmıştır. Bu yeterliklerin de iletişim yeterliğine dayandığı söylenebilir. Fullan (2008) bir kamu sektörü olarak okulların müdürlerinin bir işletme yöneticisine göre daha sık kesintiye ve iletişime maruz kaldığını, bu konuda daha savunmasız olduğunu, üstlerinden veya velilerden gelen istekler nedeniyle istemese de açı kapı politikası izlemek zorunda olduğunu belirtmektedir. Gerçeklik böyle olunca iletişim becerisi çok daha önemli hale gelmektedir.

Araştırmanın beşinci alt problemi okul müdürü olmaya katılımcıların nasıl bir anlam yüklediklerine ilişkindir. Müdürlerin anlamlandırmalarını, deneyimlerinden hareketle yaptıkları, bu nedenle okul müdürü olmaya; önder, temsilci, yönetici, karar mercii olma anlamları yanında her şeyden sorumlu olma, okulun ihtiyaçlarını karşılama gibi rutin roller de yükledikleri belirlenmiştir. Müdür olmaya yüklenen anlamlardan biri de zaman sınırı olmadan çalışmak şeklindedir. Bunun, her şeyden sorumlu olmak olarak dile getirilen çoklu rolle iliş̧ili olduğu da açıktır. Araştırmamızda, öğretmenleri desteklemekten söz edilmişse de bulgular daha çok okulun günlük rutinini sürdürme ile ilişkilidir. Bu bulgu Turan ve diğerlerinin (2012) müdürlerin kendilerini en çok insani ve maddî konularla ilgili sorumlu hissettikleri, bulgusuyla desteklenmektedir. Ayrıca bazı öğretmenler "özümüz öğretmen”, “ben aslında öğretmenim” gibi ifadelerle müdürlüğü öğretmenliğin yan branşı gibi algılar şekilde konuşmuşlardır. Turan ve diğerlerinin (2012) çalışmalarında da müdürlüğün meslek ya da görev olduğu konusunda kararsızlık yaşadıkları belirlenmiştir. Burada bir meslekleşme sorunu olduğu düşünülebilir. Türkiye'de okul yöneticisi olmak için bununla ilgili 
bir örgün eğitim almış olma zorunluluğunun olmaması, müdürlüğün meslek olarak görülmesini zorlaştırıyor olabilir. Diğer yandan alanyazında, yöneticiler için sunulan hizmet içi eğitim programlarının da daha çok bürokratik işlemler gibi teknik konulara yönelik ve kısa süreli olduğu (Balcı ve Çınkır; 2002; Erdem ve Şimşek, 2013; Gümüş ve Ada, 2017), yöneticilerin ve yönetici adaylarının bir eğitime ihtiyaç duyduğu ve eğitim almaları gerektiği (Aksu, 2004; Demirtaş ve Özer, 2014; Karakütük vd., 2019; Köse, 2008) vurgulanmaktadır.

Altıncı alt problem okul müdürü olmanın yaşattığı duyguya ilişkindir. Müdürlerin okul müdürü olmaktan dolayı ağırlıklı olarak mutluluk, sorumluluk, sevgi gibi olumlu duygular yaşadıkları belirlenmiştir. Bu anlamda, bu araştırmada, okul müdürü olma nedeni, keyif veren yönler, yaşanan duygu ve üretilen metaforlar kendi içinde tutarlılık göstermektedir. Bu araştırmaya katılan bütün müdürlerin öğretmenliği de çok sevdikleri belirlenmiştir. $\mathrm{Bu}$ bulgu, Çekiç'in (2016) yöneticiliğe olumlu yaklaşma ile öğretmenliği isteyerek seçme arasında olumlu ilişki belirleyen bulgusuyla desteklenmekte, yöneticiliğin öğretmenlikten bir kaçış gibi görülmediğini göstermektedir. Diğer yandan okul müdürlügünün duygusal dinamiklerini inceleyen oldukça az araştırma bulunmaktadır (Harris, 2007). Alanyazında da daha çok olumsuz duygular ve bunlarla baş etme stratejileri öne çıkmaktadır (Hauseman, 2020; Poirel ve Yvon, 2014).

Yedinci alt problem okul müdürü ile ilgili metaforlara ilişkindir. Üretilen metaforların hoşgörü/sakinlik, dayanıklılık/herkese yararlılık, demokratik değerler ve yöneticilik/liderlik anlamlarını vurgulayan çoğunlukla olumlu metaforlar olduğu görülmüştür. Çok çalışmaya ya da çoklu sorumluluğa yönelik metaforlar ise kısmen olumsuz olarak düşünülebilir. Araştırmamızın metafor bulguları, sorumluluk, liderlik, hoşgörü ve dayanıklılığa dayanan yönleriyle Demirtaş ve Özer' in (2014) bulgularıyla desteklenmektedir.

Sonuç olarak bu araştırmada katılımcıların müdürlüğü seçme nedenlerinin çalışmayı sevme, kendilerini yeterli görme ya da eğitim konusunda daha etkili olma amacına dayandığı belirlenmiştir. Ağırlıklı olarak finansman ve temizlik personeli sağlama konusunda zorluk yaşadıkları ve enerji harcadıkları, resmi yazışmalar gibi bürokratik işlerin kolay ama zaman alıcı olduğu anlaşılmıştır. Bütün bunlara karşın katılımcıların, çabalarının sonuç verdiğini gördüklerinde okul müdürü olmaktan dolayı olumlu duygular yaşadıkları saptanmıştır. Bu nedenle uygulamacıların, okul müdürlerini 
finansman bulma, temizlik personeli sağlama gibi, üst yönetim tarafından yapılması gereken işlerden kurtararak eğitim hizmetlerine daha fazla zaman ayıracak düzenlemeler yapmaları önerilebilir. Katılımcılara göre müdürde olması gereken kritik özelliklerin, temel insani özellikler yanında yoğunlukla iletişime ilişkin yeterlikler olduğu belirlenmiş, gerekli görülen yönetsel yeterliklerin de ağırlıklı olarak iletişimle ilişkili yönetsel yeterlikler olduğu belirlenmiştir. Bu nedenle, yöneticilerin eğitimi konusunda sistematik çalışmaların yapılması ve müdürlerin özellikle kavramsal konularda da farkındalık kazanması için zemin oluşturulması önerilebilir.

$\mathrm{Bu}$ araştırmada maksimum çeşitlilik örneklemesiyle belirlenen okul müdürleriyle çalışılmıştır. Çalışma grubu olarak yalnızca sosyoekonomik düzeyi yüksek çevrede bulunan ve görece ciddi kaynak sorunu olmayan kamu okullarının müdürlerinin alındığı bir araştırma planlanabilir. Okul müdürlerinin çalışması ile ilgili olarak mevcut durum ve olması gerekeni karşılaştırmaya yönelik bir çalışma desenlenebilir. 


\title{
EXTENDED ABSTRACT
}

\section{A Phenomenological Study on The Meaning of Being School Principal}

\author{
Pinar Yengin Sarpkaya \\ Aydin Adnan Menderes University
}

Understanding how school principals, who are the subjects of school administration, make sense of their job is important in terms of developing the process and shaping the future. However, the researches in the educational administration literature were mostly conducted with the participation of stakeholders other than the school principal. Research on the meaning of being a school principal is very limited.

It is important to see the meaning of being a principal from the perspective of individuals who experience being a principal. With this study referring to the views of the principals, it is aimed to understand both the perspective of the individuals who fulfill this critical task and to see the meaning that the principal attributes to the principal role. Therefore, the problem sentence of the research is "What is the meaning of being a school principal according to school principals?". Depending on this problem, answers to the following questions were sought:

1. Why did school principals choose to be principal?

2. What is the most difficult or challenging aspect of being a principal according to the perspectives of school principals?

3. What is the most enjoyable aspect of being a principal according to the perspectives of school principals?

4. What are the critical characteristics that principals should have according to the perspectives of school principals?

5. What does it mean to be a principal according to school principals?

6. How does being a school principal make principals feel?

7. With which metaphors do school principals explain the school principal?

The research was designed based on phenomenology, one of the qualitative research designs. The study group, determined by the maximum variation sampling, consists of 14 school principals who serve as school adminis- 
trators (in Aydin province) in Turkey. In the selection of principals, diversity has been ensured in terms of gender, seniority, education level and the school level served. The data obtained through the semi-structured interviews made with the interview form were analyzed by content analysis. The findings are grouped under seven themes (27 categories) as follows.

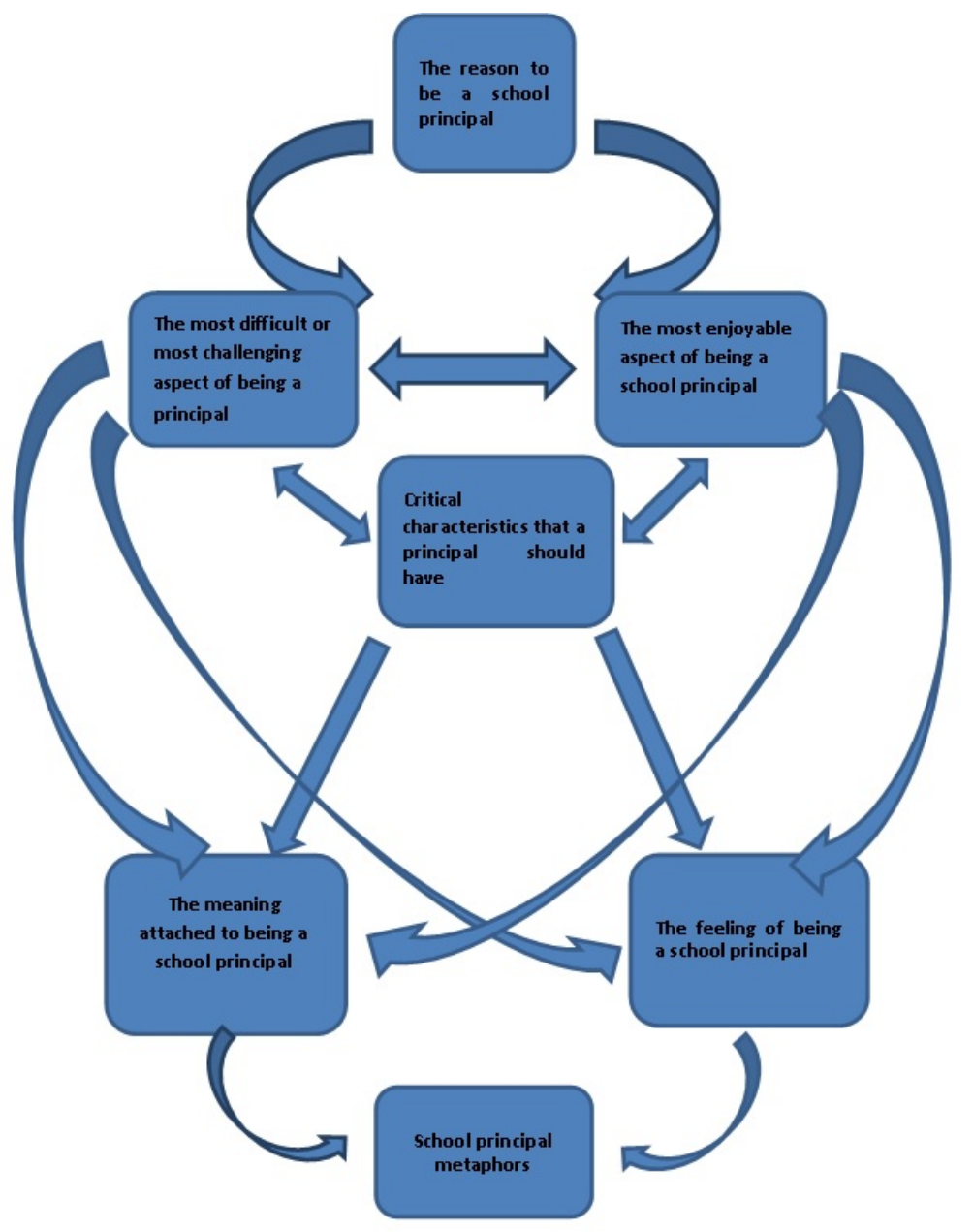

Participants explained their reasons for choosing to be a principal with intrinsic motivations such as liking to work or a desire to lead, or for benefit and service-oriented purposes. While there are principals who speak of 
external motivators, these external motives are merely causes that reinforce the internal motives a little more.

Secondly, principals emphasized issues within the scope of the management of the school enterprise, as regards the most difficult or challenging aspect of being a principal. While the public school principals emphasized the problems of providing the minimum required needs for the school to be ready for education, the private school principal emphasized the needs to increase the quality of education such as the system laboratory and technology classroom. The most important difficulties of public school principals are issues such as providing financing, finding cleaning staff, delayed budged (payment). In both public and private schools, it has been determined that giving feedback to the teacher or managing conflict - although not common - is perceived as a difficult or challenging situation for principals. While talking about the difficulty of being a principal, it was understood that principals found the paperwork and regulatory work easy but time consuming; they regard education-related jobs as easy, enjoyable but time-lacking issues, that finding time for instructional leadership is a serious challenge.

The third question of the research is about the most enjoyable aspect of being a principal. Findings about the most enjoyable aspect are generally that the studies have been successful, the students, parents and teachers are happy, and principals receive positive feedback. The findings obtained from this sub-problem and the findings obtained from the first sub-problem (the reason for being a school principal) are quite consistent. The general motivation for the participants to become administrator is to work, to serve, to be useful. The most enjoyable aspect of being a principal can be summarized as seeing that being a principal is beneficial. When talking about student happiness, principals frequently emphasized students' experiences and achievements other than their academic achievements. While expressing the pleasant aspects of being a principal, the participants used expressions such as "really difficult but I love", "really difficult but I am happy".

The fourth question of the study is about the critical characteristics that school principal should have. All the participants emphasized the individual characteristics that a person should have in general, such as being fair and respectful to people. Apart from this, the prominent finding is that all participants emphasized various characteristics related to communication compe- 
tencies. In addition, the administrative competencies were strongly emphasized as teamwork, the school principal should not stay in his room and should not govern by orders based solely on the official power. It can be said that these competencies are also based on communication competence.

The fifth question of the research is about what kind of meaning participants attribute to being a school principal. Principals make their interpretations based on their experiences, therefore becoming a school principal; in addition to the meaning of being a leader, representative, administrator, decision-making authority, they also attribute routine roles such as being responsible for everything and meeting the needs of the school. One of the meanings attributed to being a principal is to work without time limit. It is also clear that this is related to the multiple roles expressed as being responsible for everything. Although supporting teachers was mentioned in our study, the findings are mostly related to maintaining the daily routine of the school. Some participants talked about "we are teachers indeed", "I am actually a teacher" and perceive being principal as a sub-branch of teaching. It can be thought that there is a professionalization problem here. The lack of the obligation to have received a formal education related to being a school administrator in Turkey, may make it difficult to see being a principal as a profession.

The sixth question of the study is about the feeling of being a school principal. It has been determined that principals experience positive feelings such as happiness, responsibility and love due to being a school principal. In our study, the reason for being a school principal, the pleasurable aspects, the emotion experienced and the generated metaphors show consistency within themselves. It was determined that all principals participating in this study also liked being teacher very much.

The seventh question of the study is about the metaphors about the school principal. The metaphors produced are mostly positive ones emphasizing the meanings of tolerance/calmness, resilience/usefulness to all, democratic values and administratorship/leadership. Two partially negative metaphors for too much work or multi-responsibility were also produced.

Based on the findings, it may be suggested that the practitioners make arrangements to allocate more time for education services by saving school principals from the tasks that need to be done by the senior management such as finding financing and providing cleaning personnel. It may be sug- 
gested to carry out systematic studies on the training of administrators and to provide a basis for principals to gain awareness especially on conceptual issues.

A study can be planned in which only the principals of public schools are included as a study group, who are in a high socioeconomic environment and do not have a relatively serious resource problem. Regarding the work of school principals, a study can be conducted to compare the current situation and desired situation.

\section{Kaynakça / References}

Acar, Ç. (2019). İstanbul ortaokullarda görev yapan okul yöneticilerinin mesleki deneyimlerinin incelenmesi: Fenomonolojik bir çalışma. Yayımlanmamış yüksek lisans tezi. Marmara Üniversitesi, Eğitim Bilimleri Enstitüsü, İstanbul.

Açıkgöz, K. (1994). Eğitimde etkili yönetici dauranışları. İzmir: Kanyılmaz Matbaası.

Ağaoğlu, E., Altınkurt, Y., Y1lmaz, K., ve Karaköse, T. (2012). Okul yöneticilerinin yeterliklerine ilişkin okul yöneticilerinin ve öğretmenlerin görüşleri: Kütahya ili. Ë̆itim ve Bilim, 37(164), 159-175.

Aksoyalp, Y. (2010). 21. yüzyılda okul yöneticisinin niteliği: Öğretim liderliği. Sakarya Üniversitesi Eğitim Fakültesi Dergisi, 20, 140-150.

Aksu, M. B. (2004). İlköğretim okulu öğretmenlerinin yöneticilik eğilimleri: Malatya İli Örneği. İnönü Üniversitesi Eğitim Fakültesi Dergisi, 550. https://www.pegem.net/Akademi/3-8236-Ilkogretim-OkuluOgretmenlerinin-Yoneticilik-Egilimleri-Malatya-Ili-Ornegi.aspx

Amadi, E. C. (2008). Introduction to educational administration: A module. Port Harcourt: Harey Publications.

Balc1, A. (2002). Etkili okul ve okul geliştirme: Kuram uygulama ve araştırma. 3. Bask1. Ankara: Pegem Akademi Yayıncılık.

Balcı, A. ve Çınkır, Ş. (2002), Türkiye'de eğitim yöneticilerinin yetiştirilmesi. 21. yüzyıl eğitim yöneticilerinin yetiştirilmesi sempozyumu (Yay. Haz. C. Elma, Ş. Çınkır), 211-238. Ankara: Ankara Üniversitesi

Balyer, A. (2012). Çağdaş okul müdürlerinin değișen rolleri. Ahi Evran Üniversitesi Kirşehir Ĕ̈itim Fakültesi Dergisi (KEFAD) 13(2), 75-93.

Bass, T. S. (2004). Principalship inhibitors and motivators: Factors influencing educators' decisions to enter principal positions. Yayımlanmamış doktora tezi. Sam Houston State University, Huntsville, Teksas. 
Battle for Kids. (2019). Framework for 21st century learning. 11 Şubat 2020 tarihinde http://static.battelleforkids.org/documents/p21/P21_Framework Brief.pdf adresinden erişildi.

Bursalıoğlu, Z. (2015). Okul yönetiminde yeni yapı ve davranış (19. Baskı). Ankara: PEGEM Akademi Yayınları.

Bush, T. (2003). Theories of educational leadership and management. London: Sage.

Can, H. (1992). Yönetim ve organizasyon. Ankara: Siyasal Kitabevi.

Coelli, M., ve Green, D. A. (2012). Leadership effects: School principals and student outcomes. Economics of Education Review, 31(1), 92-109. https://doi.org/10.1016/j.econedurev.2011.09.001

Creswell, J. W. (2016). Nitel araştırma yöntemleri: Beş yaklaşıma göre nitel araştırma ve araştırma deseni (Çev. Ed. M. Bütün ve S. B. Demir.). Siyasal Kitabevi: Ankara.

Çekiç, B. (2016). Bahçelievlerde meslek lisesi öğretmenlerinin idareciliğe bakış açılan ve idareciliği tercih nedenleri. Yayınlanmamış yüksek lisans tezi. İstanbul Aydın Üniversitesi Sosyal Bilimler Enstitüsü, İstanbul.

Çelikten, M. (2004a). Bir okul müdürünün günlüğü. Fırat Üniversitesi Sosyal Bilimler Dergisi, 14(1), 123-135.

Çelikten, M. (2004b). Okul müdürü koltuğundaki kadınlar: Kayseri ili örneği. Erciyes Üniversitesi Sosyal Bilimler Enstitüsü Dergisi, 1(17), 91-118.

Çopur, M. ve Yengin Sarpkaya, P. (2020). Temel eğitim okullarının finansmanı hakkında yönetici görüşleri. Turkish Studies - Education, 15(3), 2245-2270. https://dx.doi.org/10.29228/TurkishStudies.42118

Deloitte Access Economics (2016). The economic impact of improving schooling quality. Canberra: Australian Government Department of Education and Training.

Demirtaş, H. ve Özer, N. (2014). Okul müdürlerinin bakış açısıyla okul müdürlüğü. Kastamonu Ĕ̆itim Dergisi, 22(1), 1-24.

Duran, A. ve Cemaloğlu, N. (2020). Başarılı okul müdürü kimliği üzerine fenomenolojik bir analiz: Alandan sesler. Necmettin Erbakan Üniversitesi Siyasal Bilgiler Fakültesi Dergisi, 2(1),12-39.

Erdem, A. R. ve Şimşek, S. (2013). Öğretmenlere ve okul yöneticilerine verilen hizmet içi eğitimlerin irdelenmesi. Uşak Üniversitesi Sosyal Bilimler Dergisi, 6(4), 94108.

Eğitim Bir Sen (2019). Eğitim çalışanlarının sorunlan ve çözüm önerileri. 15 Aralık 2020 tarihinde https://www.ebs.org.tr/yayinlarimiz/1/arastirmalar adresinden erişilmiştir.

Erginer, A., ve Köse, M. F. (2012). Okul yöneticiliğini tercih ve ayrilma nedenlerine ilişkin nitel bir çalışma. Qualitative Studies, 7(4), 14-28. 
Ersoy, A. F. (2017). Fenomenoloji. (Ed. A. Saban, A. Ersoy)Ĕ̆itimde nitel araştırma desenleri. içinde s. 81-139. Ankara: Anı Yayıncllık.

Fullan, M (2008). What's worth fighting for? (2nd edition). Amsterdam: Teachers College Press.

Fullan, M. (2018). The principal: Three keys to maximizing impact. San Francisco: John Wiley \& Sons.

Glickman, C. D., Gordon, S. P., ve Ross-Gordon, J. M. (2009). The basic guide to supervision and instructional leadership (2nd edition). Pearson: Allyn \& Bacon.

Güçlü, N. (1996). Eğitim yöneticiliği ve sosyal beceriler. Kuram ve Uygulamada Ĕ̆itim Yönetimi, 8(8), 555-564.

Gümüş, E., ve Ada, Ş. (2017). Okul müdürlerinin katıldıkları mesleki gelişim faaliyetleri hakkındaki görüşleri: Türkiye ve ABD örnekleri. Mehmet Akif Ersoy Üniversitesi Ĕ̆itim Fakültesi Dergisi, 43, 176-208.

Gümüşeli, A. İ. (2001). Çağdaş okul müdürünün liderlik alanları. Kuram ve Uygulamada Ĕ̈itim Yönetimi, 28(28), 531-548.

Gürbüz, R., Erdem, E. ve Yıldırım, K. (2013). Başarili okul müdürlerinin özellikleri. Dicle Üniversitesi Ziya Gökalp Ĕ̈itim Fakültesi Dergisi, (20), 167-179.

Hanson, E.M. (2003). Educational administration and organizational behaviour. (5th edition). Boston: Allyn and Bacon.

Harris, B. (2007). Supporting the emotional work of school leaders. London: Paul Chapman Publishing.

Hauseman, C. (2020). Strategies secondary school principals use to manage their emotions. Leadership and Policy in Schools, 1-20.

Holland, P. E. (2009). The principal's role in teacher development. Srate Journal, 18(1), 16-24.

Hord, S. (1988). The principal as teacher educator. Journal of Teacher Education, 39(3), 811.

Horng, E. L., Klasik, D., ve Loeb, S. (2010). Principal's time use and school effectiveness. American Journal of Education, 116(4), 491-523. doi:10.1086/653625

Karakütük, K ve Özdoğan Özbal, E. (2019). Eğitim yöneticilerinin yaşadıkları sorunlar ile sorun çözmede kullandıkları teknikler. Milli Ĕ̈itim Dergisi, 48(223), 33-60

Katz, R. L. (2009). Skills of an effective administrator. Brighton: Harvard Business Review Press.

Kesen, İ., Toklucu, D., Sundaram. ve Abaslı, K. (2019). Öğretim lideri vs. okul müdürü. İstanbul. SETA 
Kılıç, Y. (2020). How cultural, social, political and religious forces shape principals' roles and challenges: Evidence from four primary schools in Turkey. Yayımlanmamiş doktora tezi. University of Leicester, Leicester, England.

Köse, M. F. (2008). Yönetici adayı öğretmenlerin yöneticiliğe bakış açlan ve yöneticiliği tercih nedenleri. Yüksek lisans tezi, Gaziosmanpaşa Üniversitesi Sosyal Bilimler Enstitüsü, Tokat.

Leithwood, K., Harris, A. ve Hopkins, D. (2008) Seven strong claims about successful school leadership. School Leadership and Management, 28(1), 27-42, DOI: 10.1080/13632430701800060 https://doi.org/10.1080/13632430701800060

Mintzberg, H. (2007). The manager's job: Folklore and fact. Leadership: Understanding the dynamics of power and influence in organizations (Ed. Vecchio, R. P.) içinde ss. 35-53. Indiana: University of Notre Dame Press.

Morgan, T. L. (2018). Assistant principals' perceptions of the principalship. International Journal of Education Policy and Leadership, 13(10), 1-20.

Newton, P. M., ve Wallin, D. (2013). The teaching principal: An untenable position or a promising model?. Alberta Journal of Educational Research, 59(1), 55-71.

OECD (2017). Education at a Glance 2017: OECD Indicators. Paris: OECD Publishing. DOI: http://dx.doi.org/10.1787/eag-2017-en.

OECD (2020). TALIS 2018 results (Volume II): Teachers and school leaders as valued professionals. Paris: OECD Publishing. DOI: https://doi. org/10.1787/19cf08df-en.

Oplatka, I. (2004) The principalship in developing countries: Context, characteristics and reality. Comparative Education, 40(3), 427-448, DOI:10.1080/0305006042000274872

Patton, M. Q. (2014). Nitel araştırma ve değerlendirme yöntemleri. (Çev. Ed. M. Bütün ve S. B. Demir). Pegem Akademi: Ankara.

Poirel, E., ve Yvon, F. (2014). School principals' emotional coping process. Canadian journal of education, 37(3), 1-23.

Robbins, S. P., Coulter, M. K., ve DeCenzo, D. A. (2017). Fundamentals of management.(11th Edition). New York: Pearson.

Sergiovanni, T. J., \& Starratt, R. J. (1979). Supervision: Human perspectives. (2nd ed.). New York: McGraw-Hill.

Sergiovanni, T.J., Kelleher, P., McCarthy, ve Wirt, F.M. (2004). Educational governance and administration (5th ed.). Boston: Pearson.

Sharp, W. L., ve Walter, J. K. (2003). The principal as school manager. (2nd ed.) Oxford: The Scarecrow Press, Inc. 
Şişman, M. ve Turan, S. (2004). Dünyada eğitim yöneticilerinin yetiştirilmesine ilişkin başıca yönelimler ve Türkiye için çıkarılabilecek bazı sonuçlar. Türk Eğitim Bilimleri, 2(1), 13- 25.

Trnavčevič, A., ve Roncelli Vaupot, S. (2009). Exploring aspiring principals' perceptions of principalship: A Slovenian case study. Educational Management Administration \& Leadership, 37(1), 85-105.

Turan, S., Yıldırım, N., ve Aydoğdu, E. (2012). Okul müdürlerinin kendi görevlerine ilişkin bakış açları. Pegem Ĕ̆itim ve Öğretim Dergisi, 2(3), 63-76.

Ünal, A. ve Çelik, M. (2013). Okul yöneticilerinin öğretimsel liderlik davranışı ile öğretmenlerin örgütsel vatandaşlık davranışlarınn analizi. Uşak Üniversitesi Sosyal Bilimler Dergisi,

$6(2)$, 239-258. https://dergipark.org.tr/tr/pub/usaksosbil/issue/21643/232666 Yeşilkaya, Ş, (2007). Öğretmenleri yönetici olmaya güdüleyen etkenler. Yüksek Lisans Tezi, Yeditepe Üniversitesi Sosyal Bilimler Enstitüsü, İstanbul.

\section{Kaynakça Bilgisi / Citation Information}

Yengin Sarpkaya, P. (2021). Okul müdürü olmanın anlamı üzerine bir olgubilim çalışması. OPUS-Uluslararası Toplum Araştırmaları Dergisi, 17(35),1785-1822. DOI: 10.26466/opus.885162 